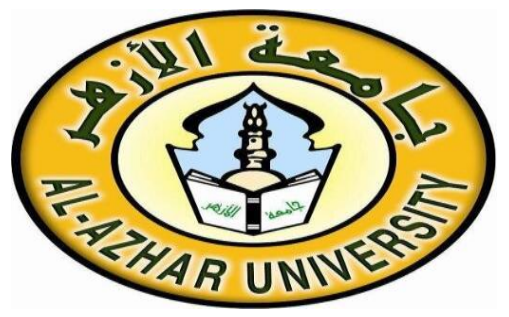

\section{جامعة الأزهر}

كلية الدراسات الإسلامية و العربية للبنين بالديليامون - شرقية

\title{
اللآلئ البهينة
}

في نقد نظريَّة المثل والمثثول عند الباطنية

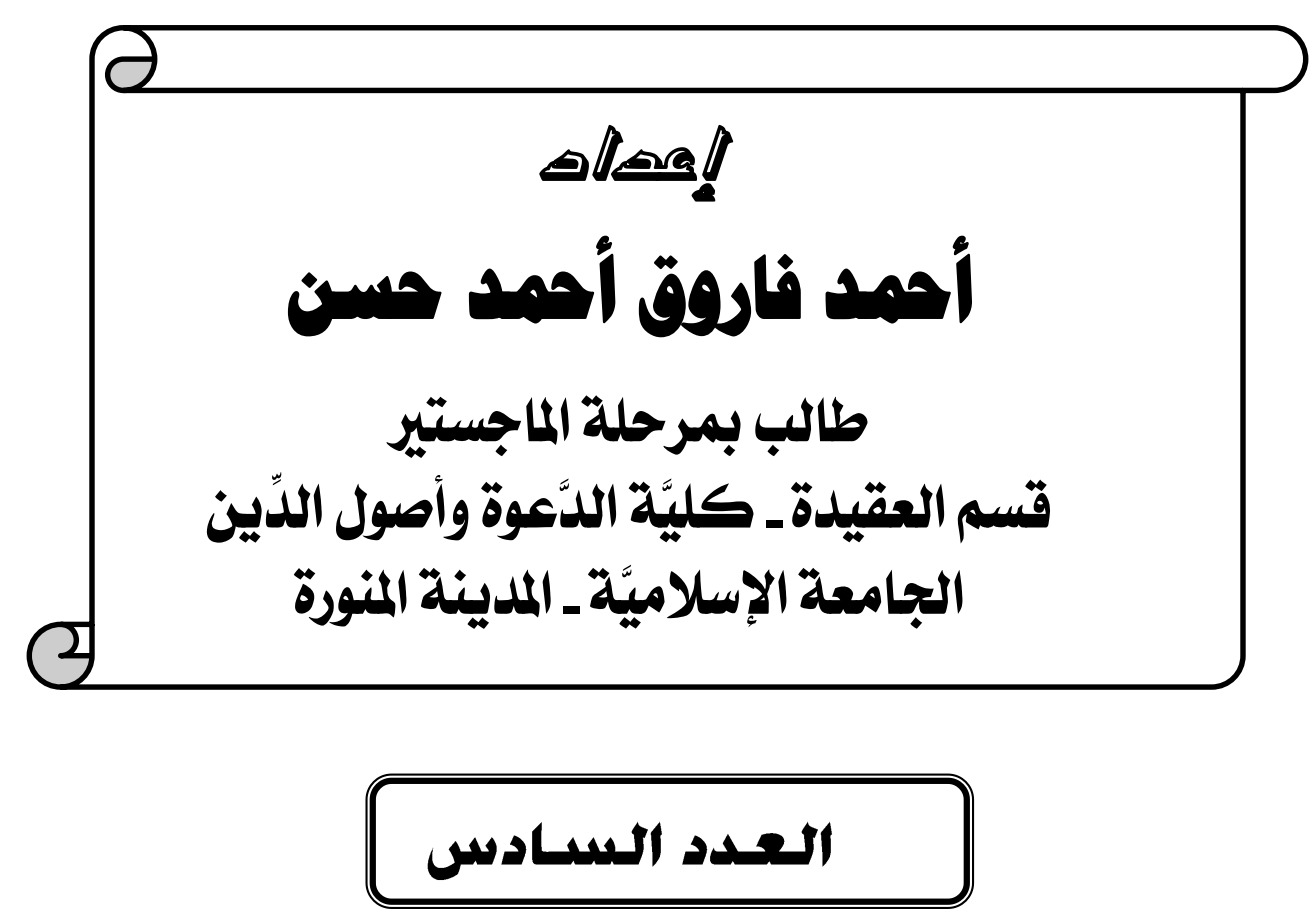

$p r \cdot 19 /$ | I 


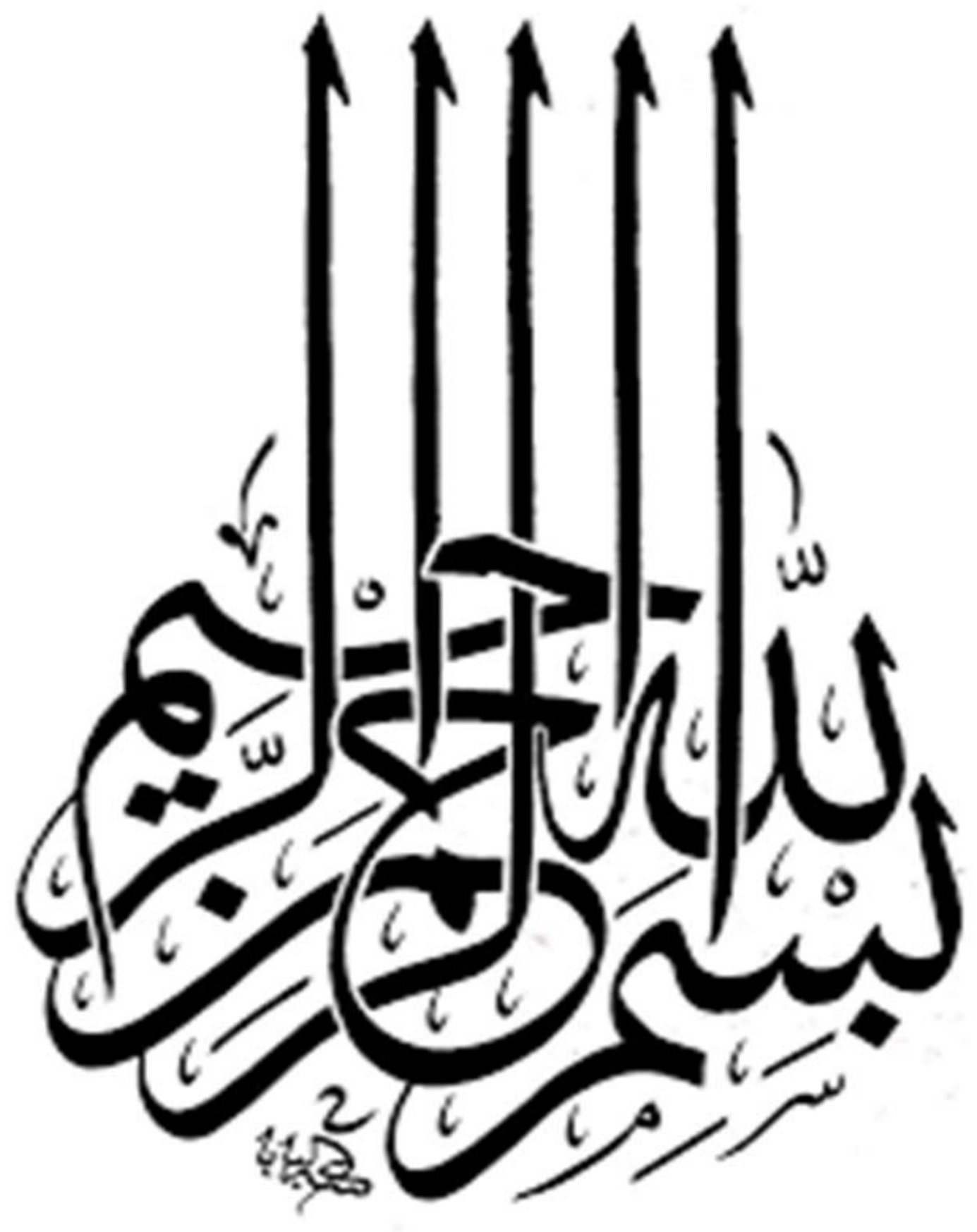




\section{ملذّ صَ البحث}

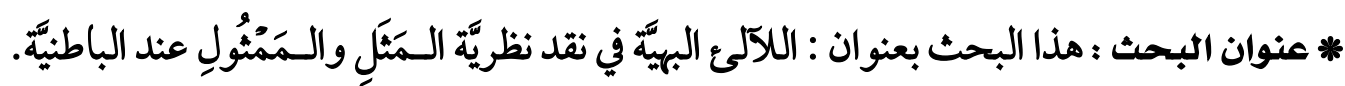
* منهج البحث : اعتمد البحث علئ المنهج الاستقرائي التحليلي. * أهداف البحث : تتضح أهداف البحث حول نقد نظريَّة (الـمَتِلِ والـمَمْثُولِل)، عند الباطنيَّة. * محتوى البحث : يشتمل البحث علئ المباحث الآتية :

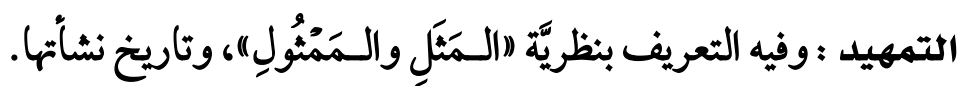

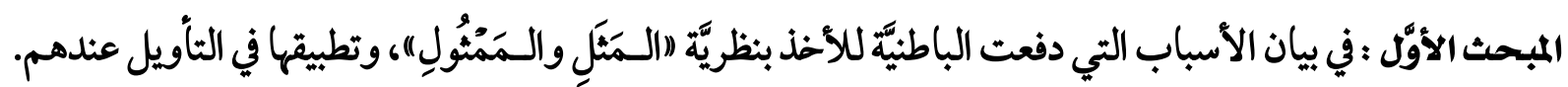

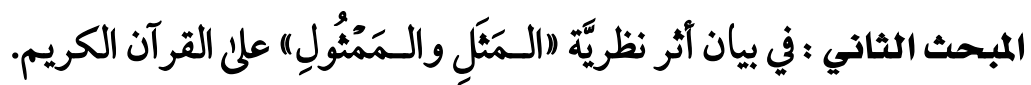

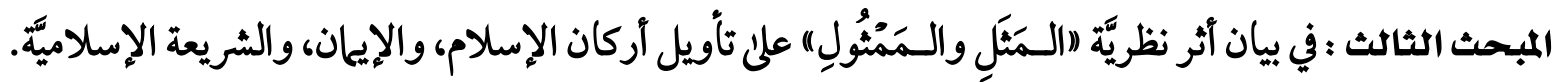

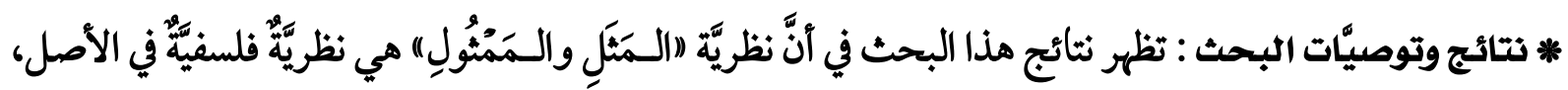

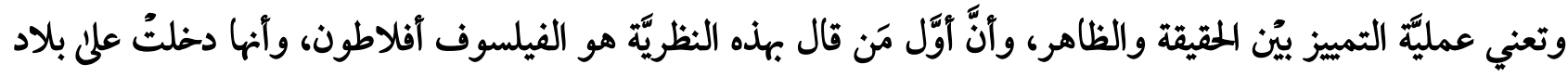

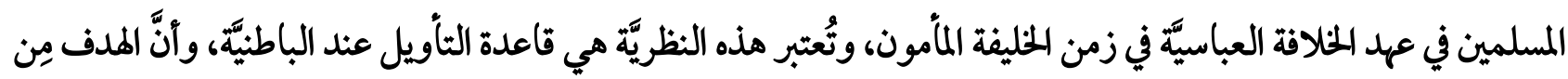
هذه النظريَّة هو الانسلاخ مِن الدِّين الإسلامي.

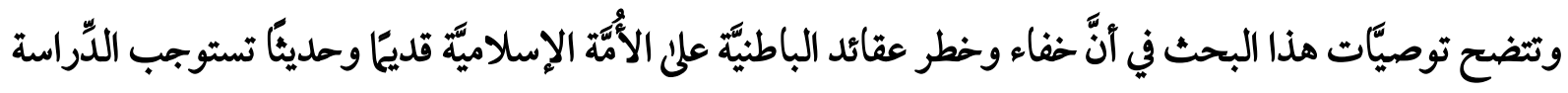
لهذه العقائد، ونقدها وتفنيدها عبر وسائل الإعلام، والقنوات الفضائَّة؛ وذلك لتحذير المسلمين مِن هذه العقائد الإلحاديَّة الكُفريَّة.

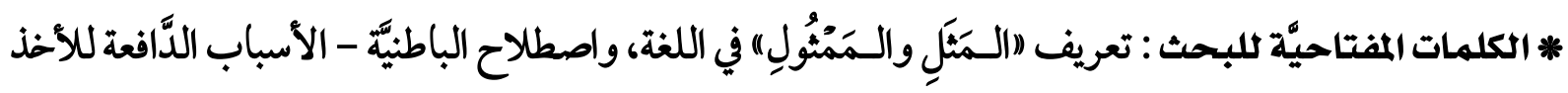
بنظريَّة (الـَمَكَلِ والـمَمْثُولِل). أمد فاروق أحمد حسن

ahmedelqasim@gmail.com 


\section{Research Summary}

${ }^{*}$ Research Title : This research is entitled: Pearls Gorgeous in the critique of the theory of ideals and Memthol when esoteric.

${ }^{*}$ Research Methodology: The research was based on the inductive analytical method. *Objectives of the research: The objectives of the research is clear about the critique of the theory of "ideals and ideals", when the esoteric.

*Search Content: The research includes the following topics

Introductory: The definition of the theory of "ideals and ideals", and the date of origin. The first topic: In the statement of the reasons that led the esoteric to take the theory of «ideals and Memthol», and applied in their interpretation.

The second topic: in the statement of the impact of the theory of "ideals and ideals" on the Koran.

The third topic: in the impact of the theory «ideals

The representative »to interpret the pillars of Islam, faith, and Islamic law.

*The results and recommendations of the research: The results of this research show that the theory of "ideals and ideals" is a philosophical theory in origin, and means the process of distinguishing between truth and apparent, and that the first to say this theory is the philosopher Plato, and that entered the time of the Muslim era in the era of the Caliphate Caliph al-Ma'mun, this theory is the basis of interpretation in the esoteric, and that the aim of this theory is to break away from the Islamic religion.

It is clear from the recommendations of this research that the invisibility and danger of the esoteric doctrines of the Islamic Ummah, old and new, require study of these beliefs, criticism and refutation through the media, and satellite channels, in order to warn Muslims of these atheistic atheistic doctrines.

Research Keywords: Definition of "Ideal and Represented" in Language, and the Idiom of Esotericism - Reasons

The impetus to adopt the theory of "ideals and appearances

\section{Ahmed Farouk Ahmed Hassan}

ahmedelqasim@gmail.com 


$$
\text { بسم الله الرحمن الرحيهم }
$$

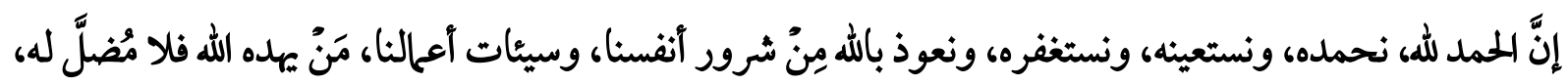

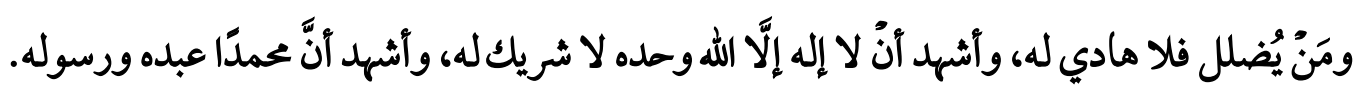

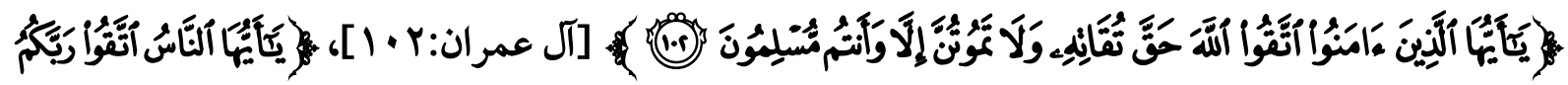

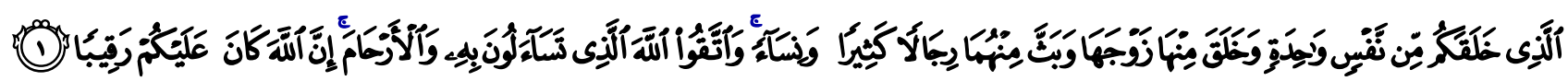

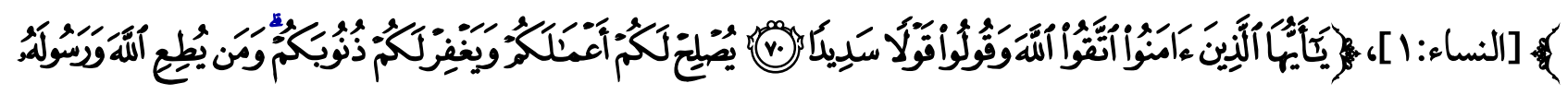

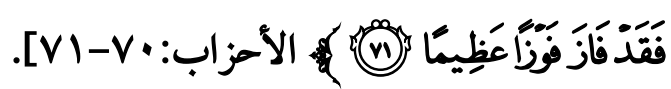

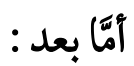

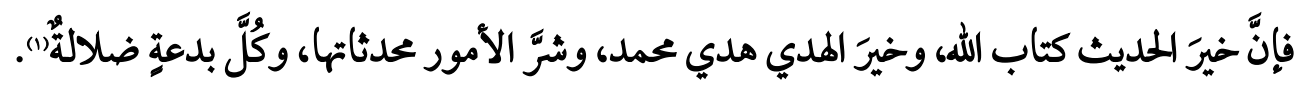

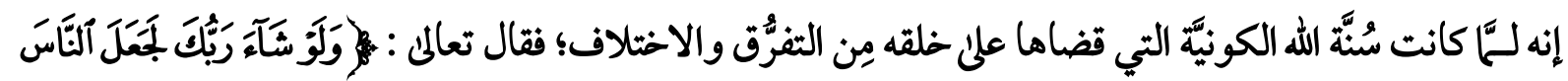

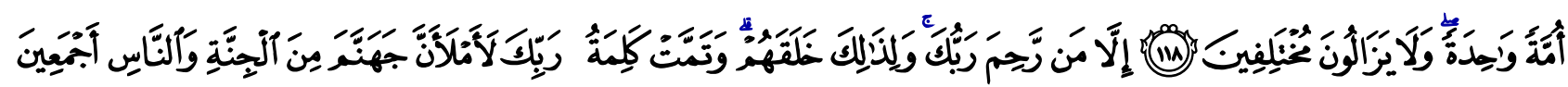

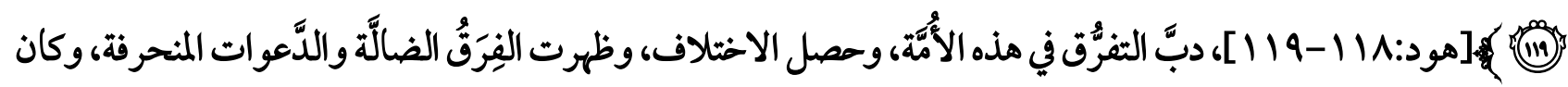

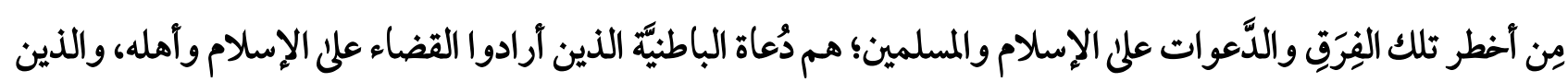

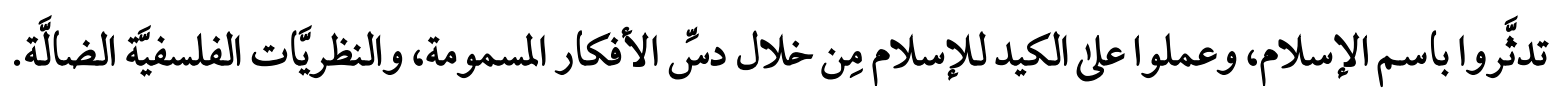

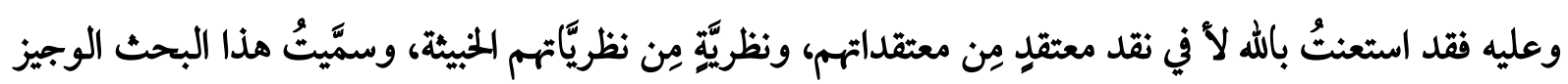

\section{السآلكئ البهنية \\ في نقد نظرية المثل والممثول عند الباطنية.}

(1) أخرجه مسلم في (صحيحها) - كتاب الجمعة - باب تخفيف الصلاة والمطبة - برقم (ATV) مِن حديث جابر بن عبداللهب. 


$$
\begin{aligned}
& \text { هُ أهميَّة الموضوع : } \\
& \text { تكمُن آهميَّة الموضوع فئموض النقاط الآتية : }
\end{aligned}
$$

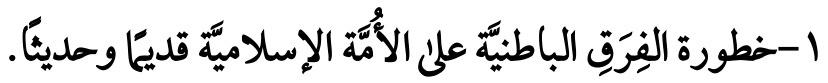

$$
\begin{aligned}
& \text { Y- بخفاء معتقدات الباطنيَّة على كثيِيِ مِن الناس. }
\end{aligned}
$$

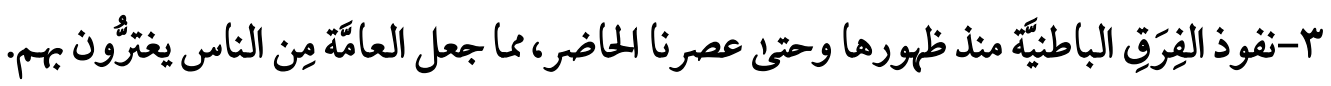

ع-كثف عوار هذه الفِرقِقِة الخارجة مِن الدِّين، وبيان ما تحمله مِن عقائد ضالَّة وخبيثة.

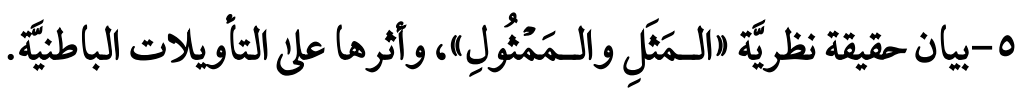
" سبب اختيار الموضوع :

ترجع أسباب اختيار الموضوع إلى النقاط الآتية :

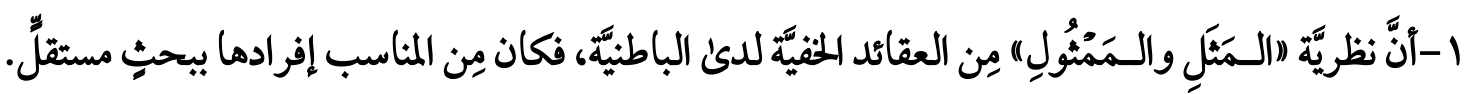

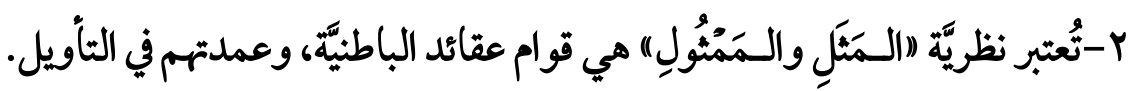
ب-عظيم اللحاجة إلى بيان خطورة هذه النظريَّة، وييان زيفها وبطلانها. ع-عدم وجود دراسة وافية ومستقلّة حسب عِلْمي واطلاعي لهذه النظريَّة.

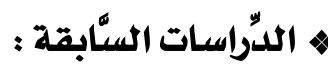

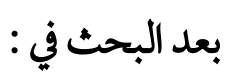

مركز الملك فيصل للبحوث والدّراسات الإسلاميَّة. لم الجدد أنَّ هذا الموضوع قد بُحث وأُفرد ببحثِ مستقلً. | أسئلة البحث :

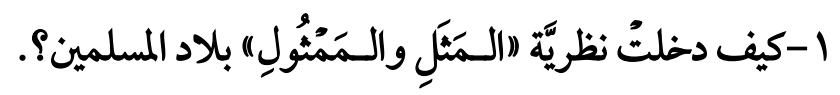

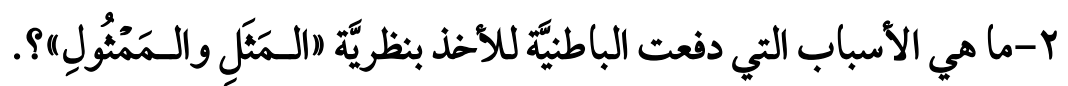
| أهداف البحث :

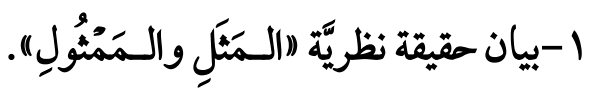

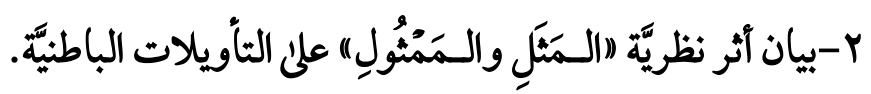
ه خطة البحث :

تتكون خطة البحث مِن مُقدِّمة، وتهيديد، وثلاثة مباحث، وخاتمّة، وهي كالآتي : 


$$
\begin{aligned}
& \text { r-سبب اختيار الموضوع. } \\
& \text { ب-الدّرّاسات السَّابقة. } \\
& \text { ع-أسئلة البحث. } \\
& \text { ه-أهداف البحث. } \\
& \text { ז-خطة البحث. } \\
& \text { V-منهج البحث. } \\
& \text { التههيد : } \\
& \text { وتحته ثلاثة مطالب : }
\end{aligned}
$$

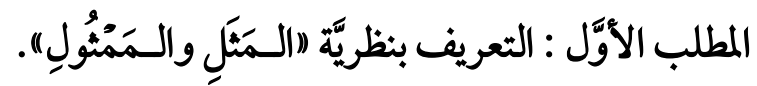

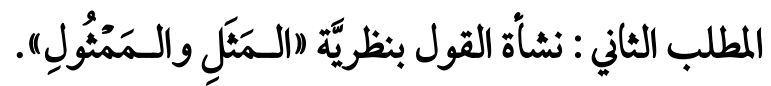

المطلب الثالث : التعريف بالباطنيَّة.

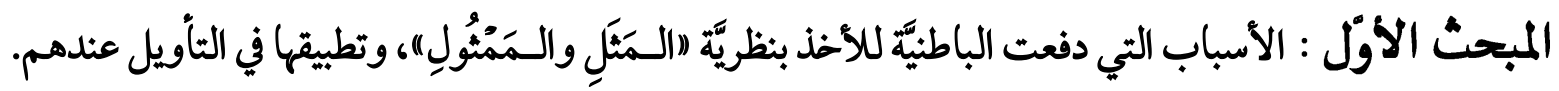

$$
\text { وتمته مطلبان : }
$$

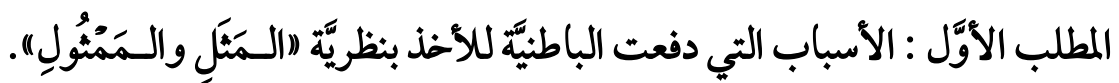

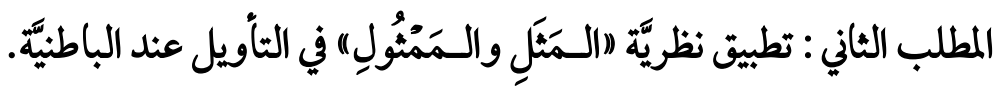

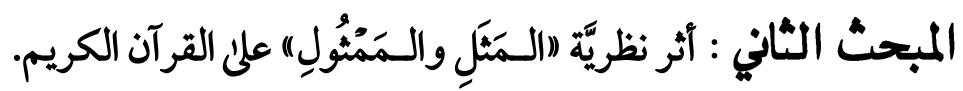

$$
\text { وتحته مطلبان : }
$$

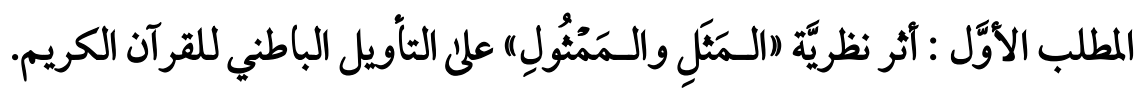

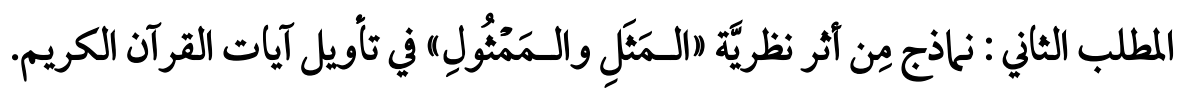

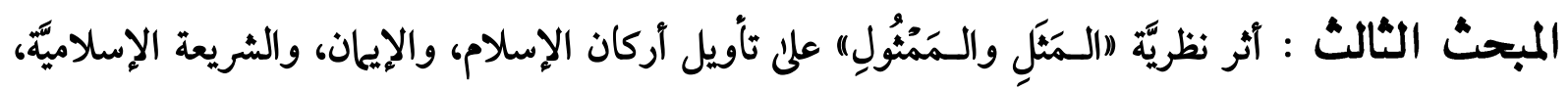

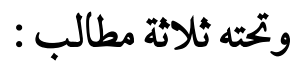

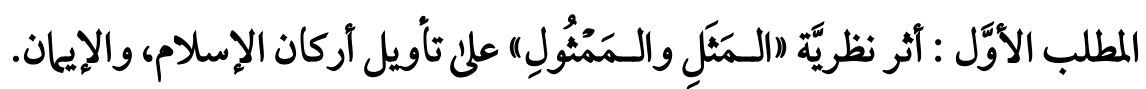

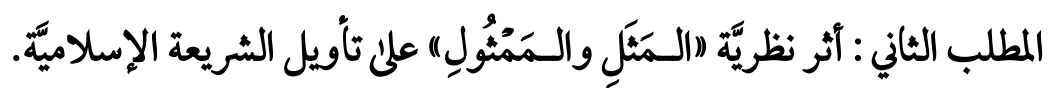

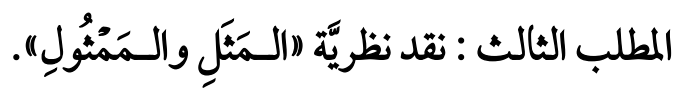

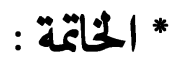
وتشتمل علني أهم التتائج والتوصيّكتات التي جاءتُ في هذا البحث. 


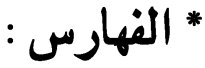

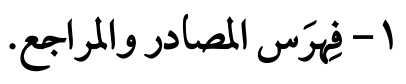

$$
\begin{aligned}
& \text { r- بفِرَس الموضوعات. } \\
& \text { هنهج البحث : } \\
& \text { المنهج المتّبَع في هذا البحث هو المنهج الاستقرائي التحليلي. }
\end{aligned}
$$

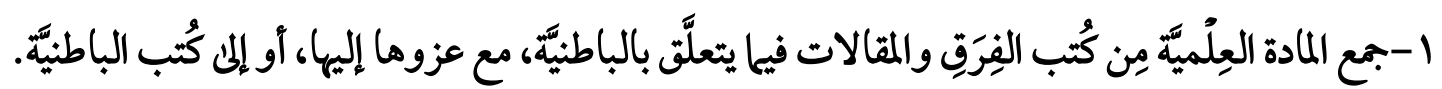

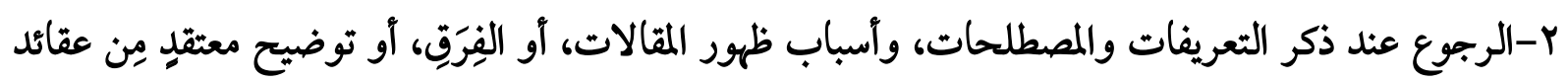
الباطنيَّة أرجع في ذلك إلى الكُتب المصنَّفة في هذا الفنّ. ب-توثيق النُّول وعزوها إلى مصادرها الأصليَّة. ع-عزو الآيات القرآنيّة، مع ذكر اسم السُّورة، ورقم الآية، وكتابتها بالرَّسم العثلماني. ه-تخريج الأحاديث النبويَّة مِن مصادرها الأصليَّة، وهي على النحو الآتي: أ-إن كان المديث في الصحيحيُن، أو أحدما، أكتفي بالعزو إليهلا.

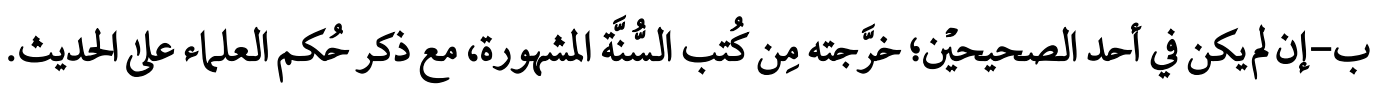
צ-الترجمة للأعلام الواردة أسماؤهم في هذا البحث.

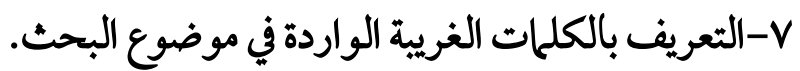
^-التعريف بالبلدان الواردة في هذا البحث. هذا وصلَّلَ الله وسلَّم ويارك على نبيّنا محمد وعلى آله وصحبه أجمعين 


\section{| التهم-}

المطلب الأولَّل : التعريف بنظريَّة (الهمَتَلِ واللمَمْنُولِ)ِ

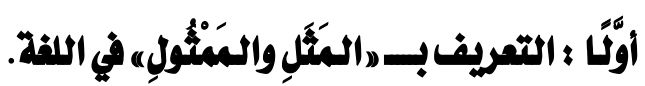

$$
\text { ا- تعريف (اللمَنَلِ)" . }
$$

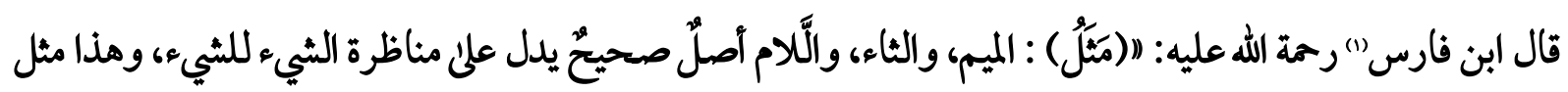

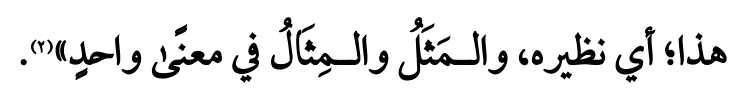
ومنه قيل :

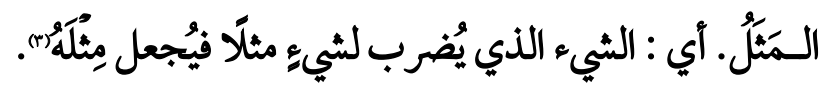

$$
\begin{aligned}
& \text { مثال الثيء. آي :صفته(s). }
\end{aligned}
$$

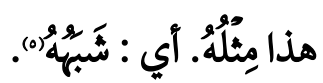

$$
\begin{aligned}
& \text { ب- تعريف ((الهمَمْثُولِ) . } \\
& \text { فقيل : هو ما يُذكر لإيضاح القاعدة بتحام إثارتها(). }
\end{aligned}
$$

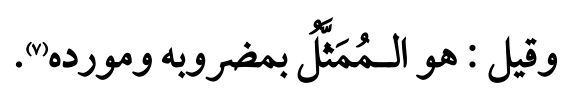

كأن يقال : هذا كمثل هذا. أي صفته كصفته (1).

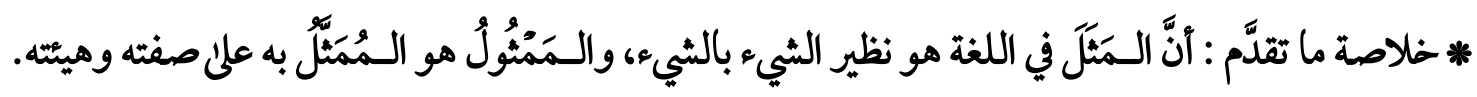

(1) هو العلَّامة، اللُلغوي، المحلِّث، أبو الحسين، أحمد بن فارس بن زكريا بن محمد بن حبيب القزويني، الرَّازي، الملالكي، نزيل (اهذان)، صاحب

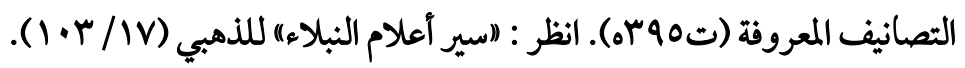

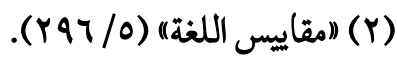

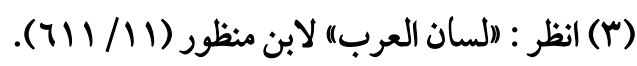

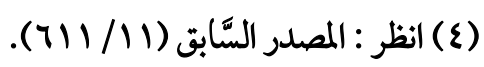

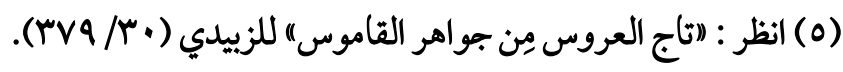

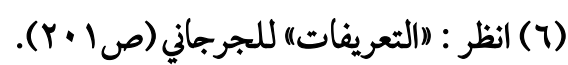

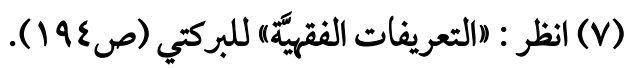

$$
\begin{aligned}
& \text { (1) انظر : (الفروق اللغويَّة) للعسكري (ص ع 1 ) ). }
\end{aligned}
$$




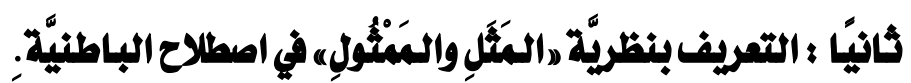

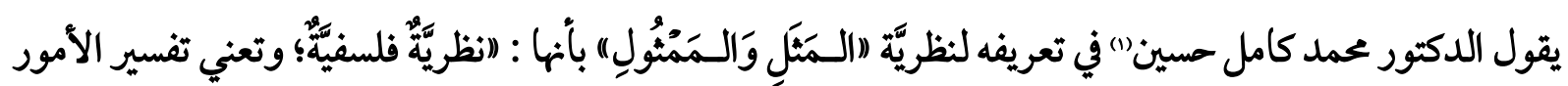

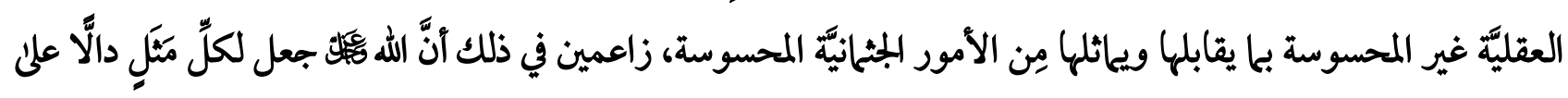

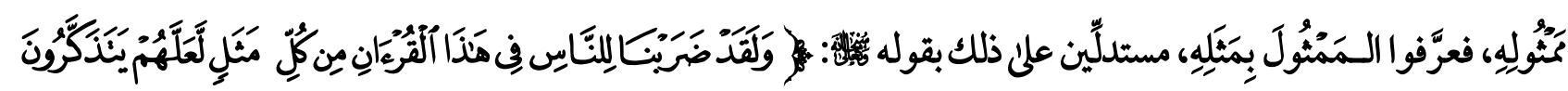

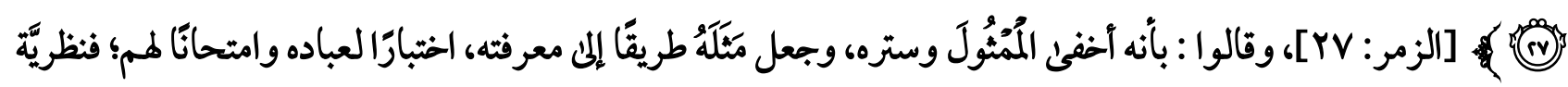

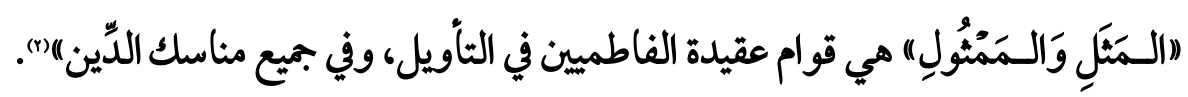

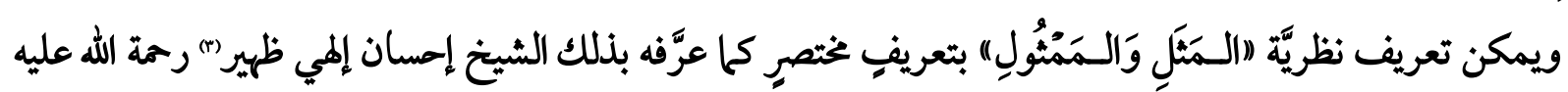

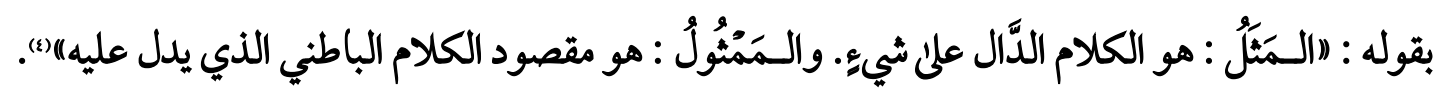

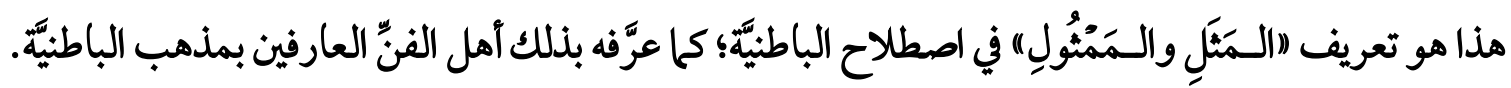

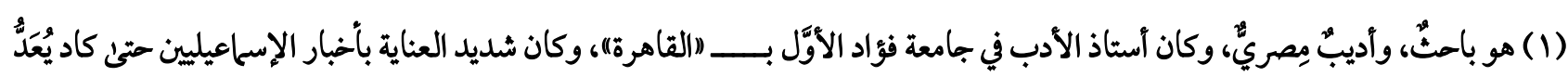

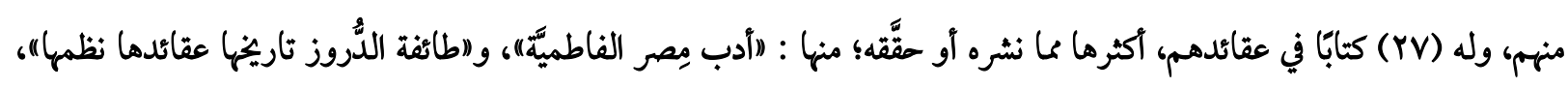

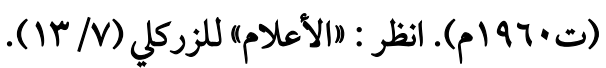

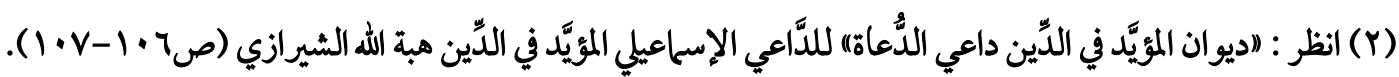

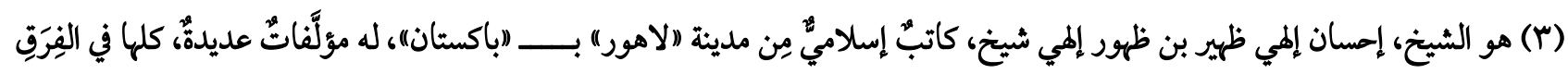

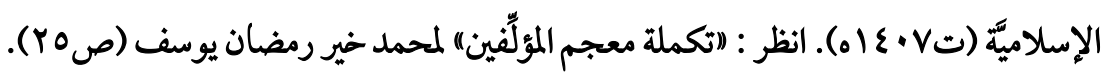

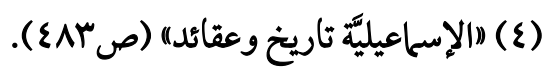




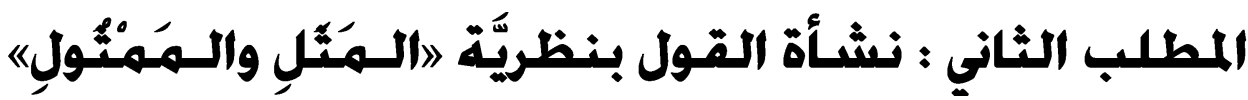

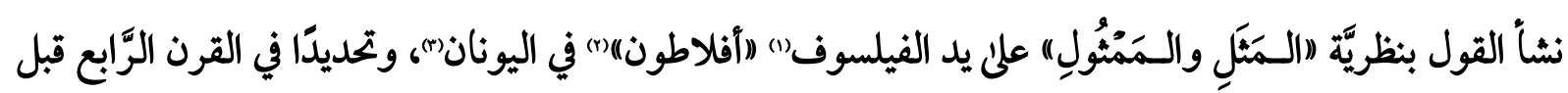
الميلاد، وكان رأيه بهذه النظريَّة هو عمليَّة التمييز بينّ الحقيقة والظاهر (3).

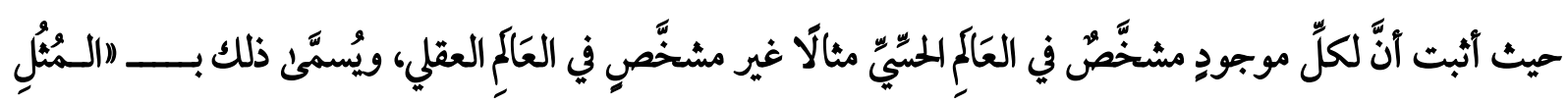

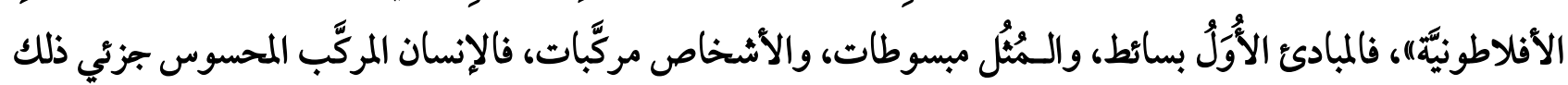

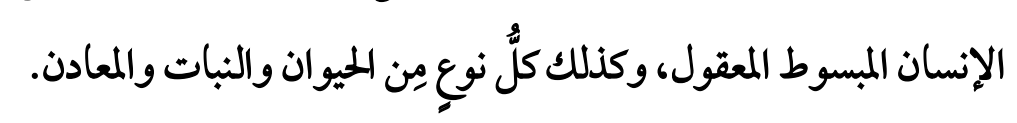

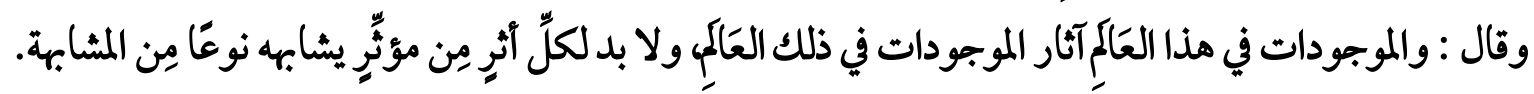

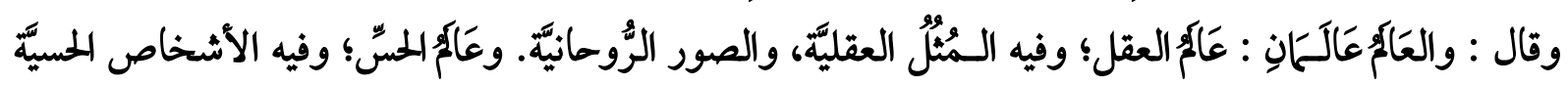
والصور المجسمانيَّةَ.). وأفلاطون إذ يقول ذلك المعنى الذي أثبته في العقل فإنه ييب أن يكون له شيءُ يطابقه في الخارج فينطبق عليه وياثله؛

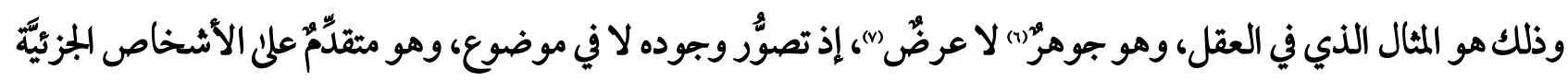

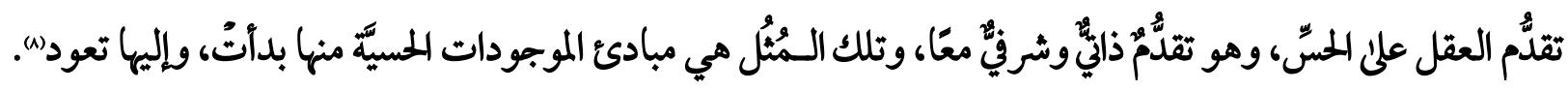

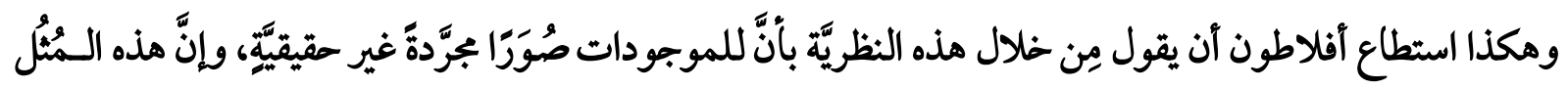

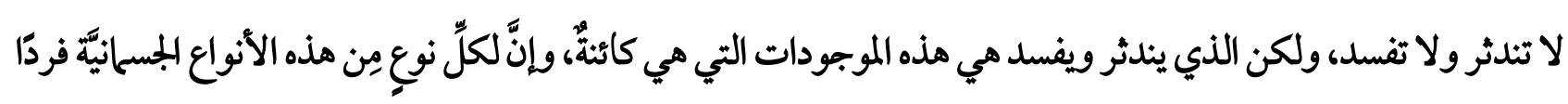

(1) (الفيلسوف) : هي كلمةُ يونانيَّ؛ وتعني : محب المكمة، أصله (فيلا) وهو المحب،، و(اسوفا) وهي المكمة، والاسم الفلسفة. انظر : (البلاسوس على القاموس" للشدياق (ص (Y) (Y).

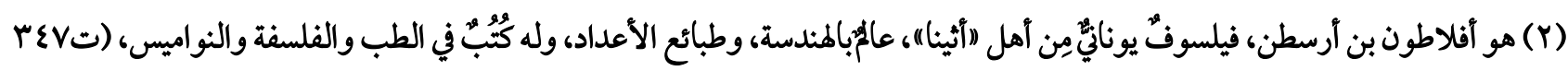

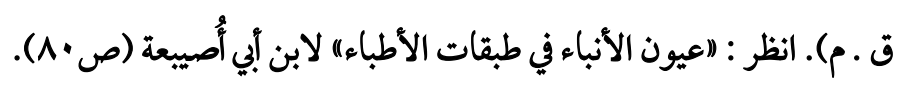

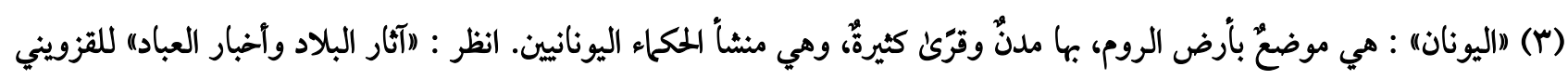
(ص) (ص79).

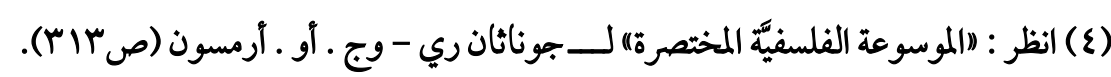

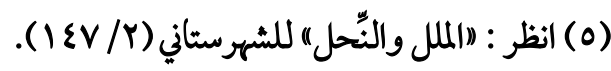

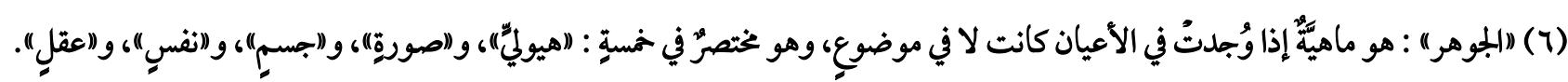

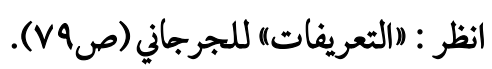

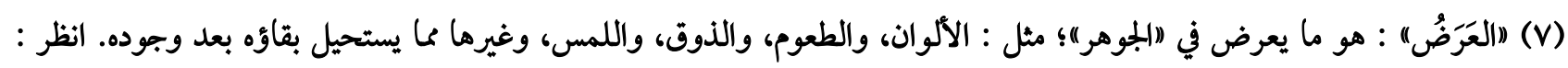

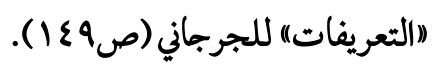

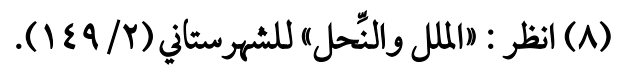


في عَالمالعقل.

وهنا سؤالْ مهِّ؛؛ وهو كيف دخلتُ هذه النظريَّة بلاد المسلمين؟

وييبب عن هذا السؤال الدكتور محمد كامل حسين بقوله : (إنَّ هذه النظريَّة وإن كانتُ قدصُبغتُّ بالصبغة الإسلاميَّة،

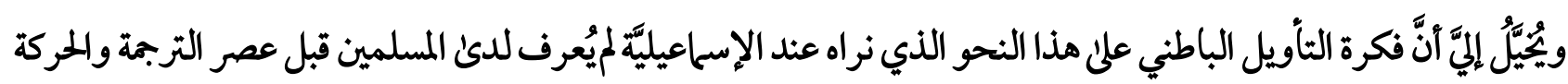

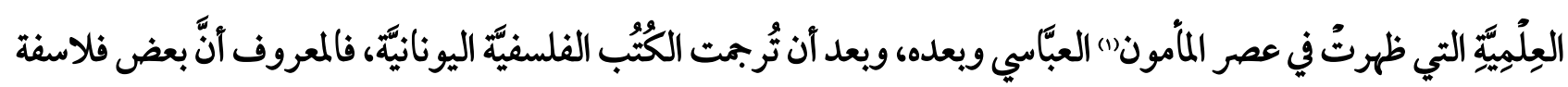

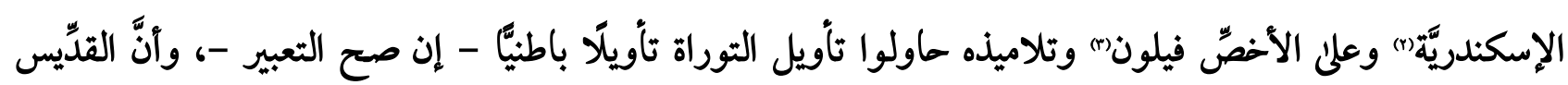

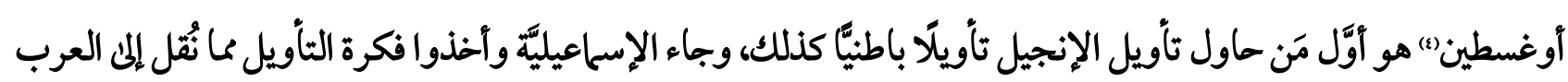

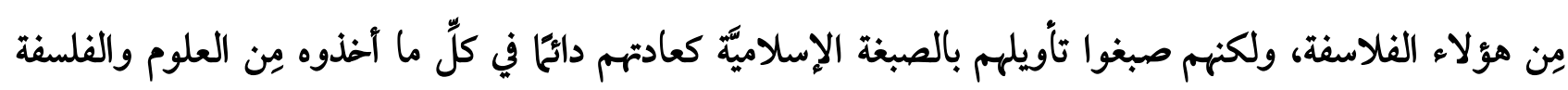
الأجنبيَّة)(ا).

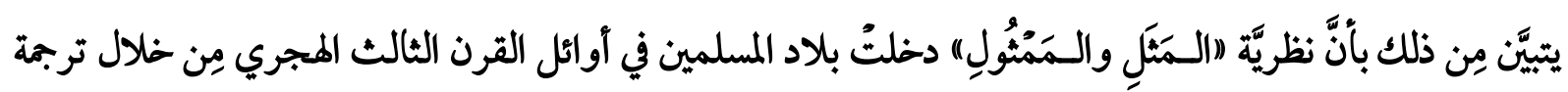
كُتبُ الفلاسفة التي تُرجمتُ في هذا العصر، وعليه فقد آخذت الباطنيَّة هذه النظريَّة وطبَّتها في تأويلاتها المخبيثة.

(1) هو المليفة، أبو العباس، عبد الله المأمون بن هارون الرشيد، كان ذا رأي وعقلِ، ودهاءٍ وشجاعِة، وكرم وحلمِ، ومعرفة بعلم الأدب، وعلومِ

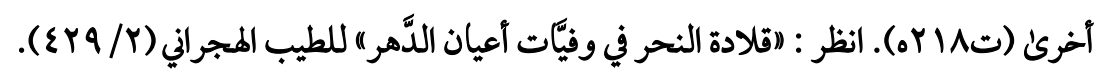

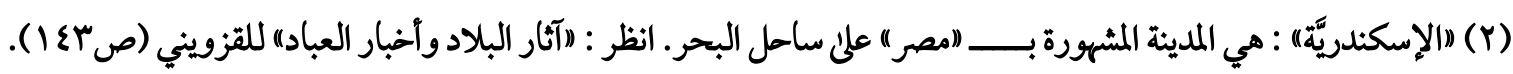

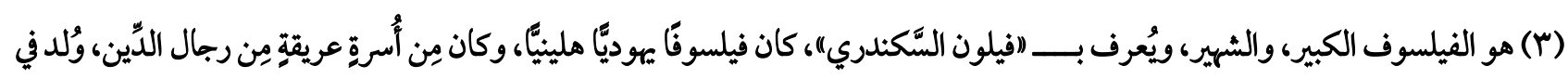

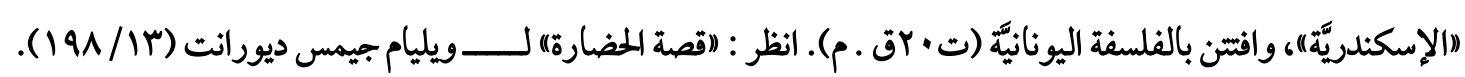

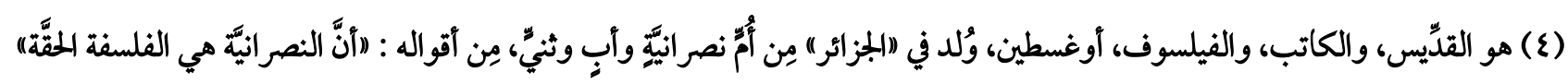

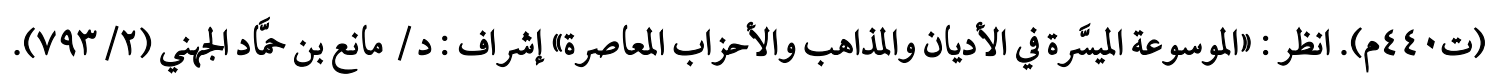

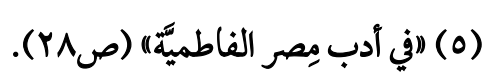




\section{المطلب الثالث : التعريف بالباطنيَّة}

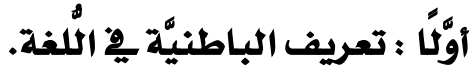

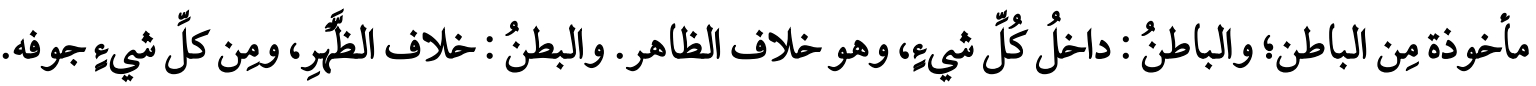

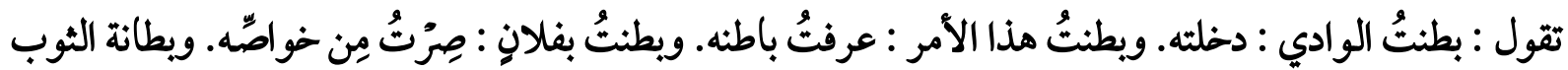

: خلاف ظهارته. وياطن الأمر : خلاف ظاهره".

ثانيًا : تعريف الباطنيَّة فِ الاصطلاح.

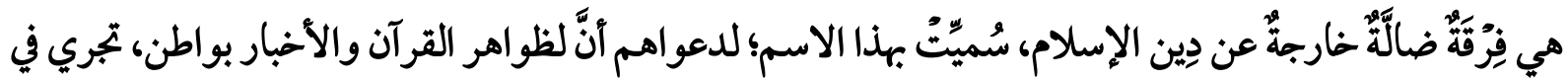

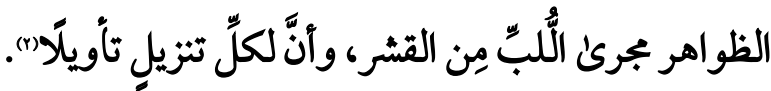

(1) (انظر : (الصحاح تاج اللغة وصحاح العربيةًا) للجوهري (Y) (Y) (Y). (Y).

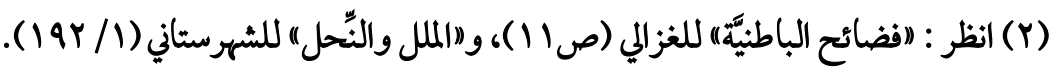




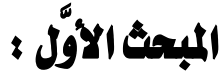

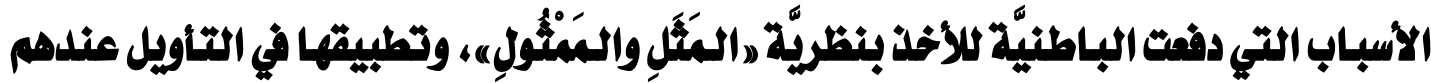

المطلب الأوَل : الأسباب التي دفعت الباطنيَة للأخذذ بنظريَّة (المَثَلِ والمَمْئُولِي)

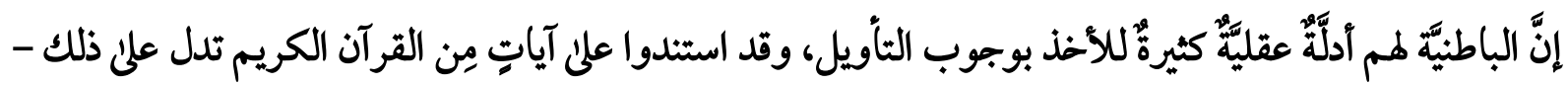

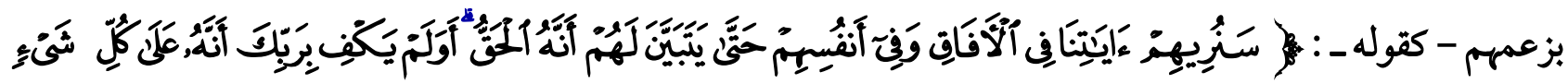

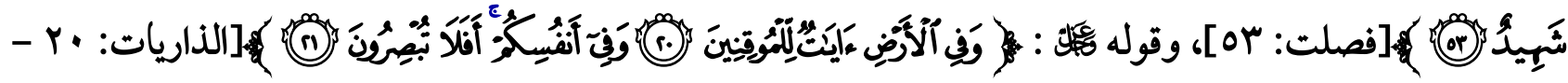

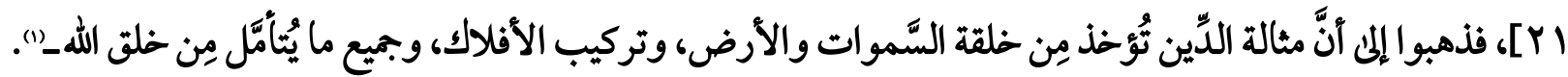

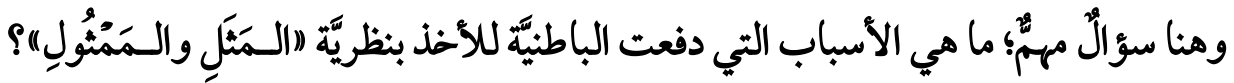

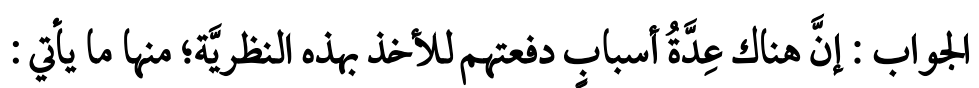

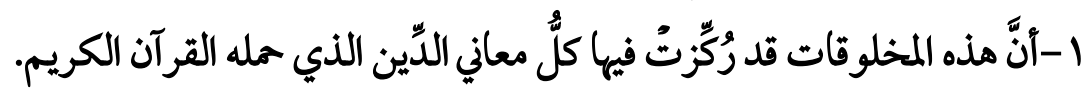

$$
\begin{aligned}
& \text { r- بأنَّ القرآن الكريم بحاجة إلمى مَن يخرج كنوز هذه المعاني. } \\
& \text { ب- بأنَّ هذه المخلوقات تنقسم إلى قسميْن : } \\
& \text { أ-قسمّ ظاهرٌ للعيان. }
\end{aligned}
$$

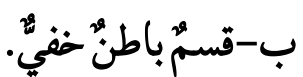

ع-الغلو في زيادة شرف عليّ بن أبي طالبِ س والأئمة مِن أهل بيته ش، وخصّهم بميزاتِ عن سائر البشر؛ وهو عِلْمُ

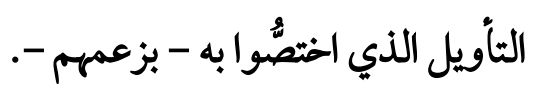

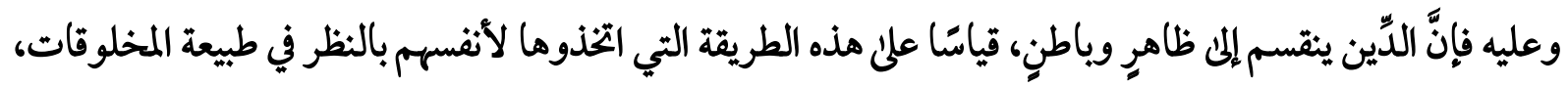

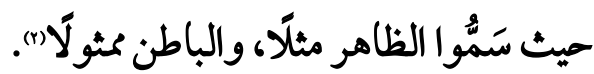

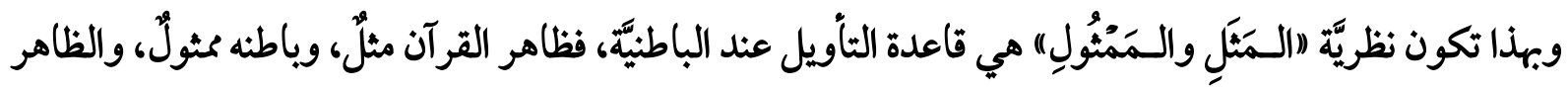
: هو هذه المعاني التي يعلمها العامَّة، وينطق بها علماء أهل السُّنَّة، والباطن : هو هذه المعاني التي يستخلصها الوصي والأئمة مين أهل البيت دون سواهم مِن سائر المسلمين" (r).

$$
\begin{aligned}
& \text { (1) انظر : (افي أدب مِصر الفاطميَّة) لمحمد كامل حسين (صVY). } \\
& \text { (Y) انظر : المصدر السَّابق (صVI) (YV). }
\end{aligned}
$$

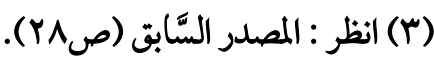


ولقد جعلوا هذه النظريَّة مِن الخصائص التي يختصُّون بها عن غيرهم، ويعدُونها مِن مفاخرهم في تمسكهم بالتأويل

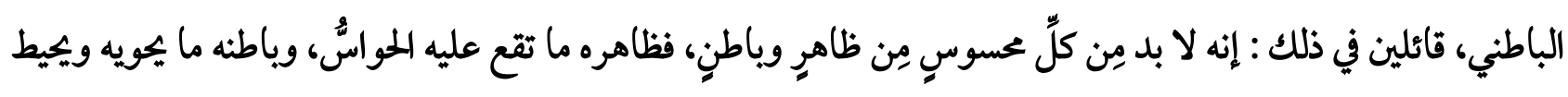

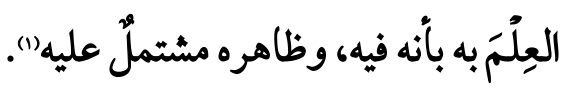

(1) انظر : (أساس التأويل) لللدَّاعي الإسماعيلي النعان بن حيُّون (ص^Y). 17 


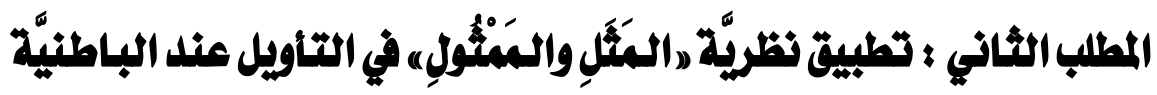

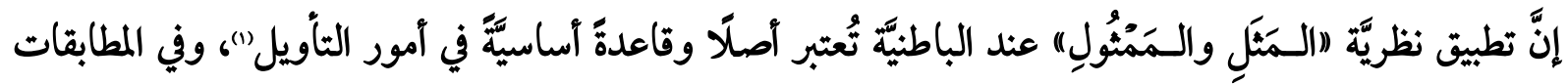

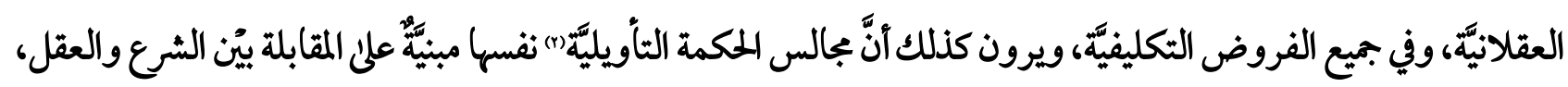

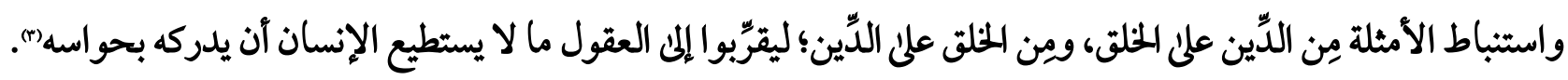

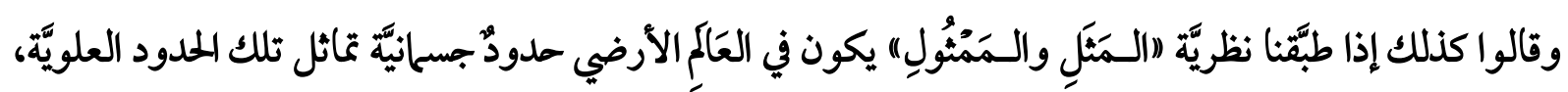

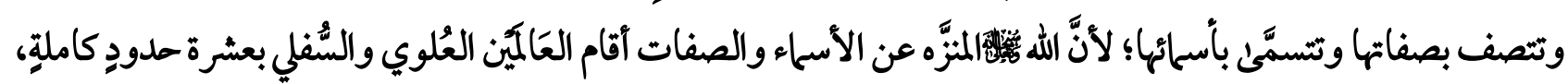

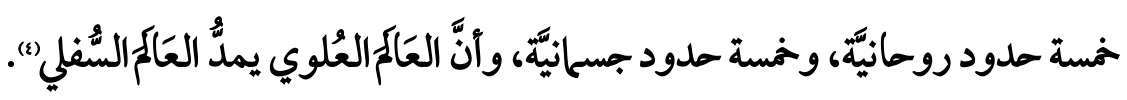

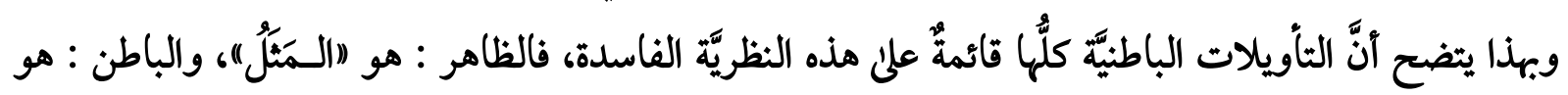

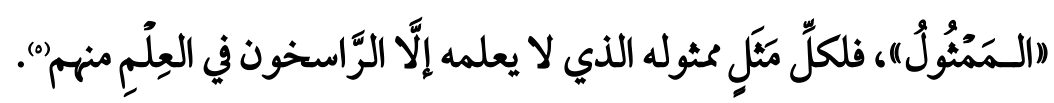

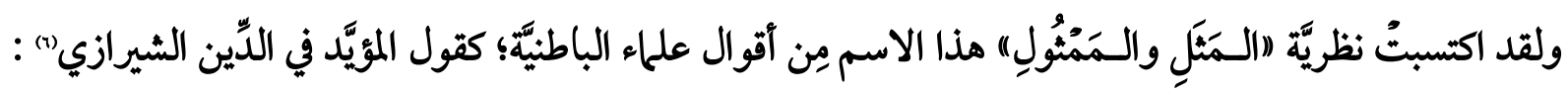

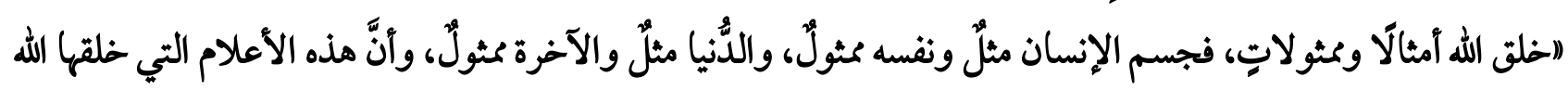

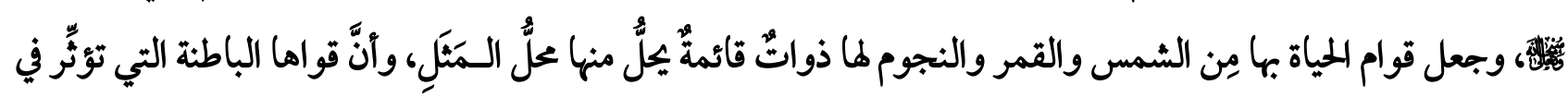
المصنوعات هي مثثول تلك الأمثال) (ب).

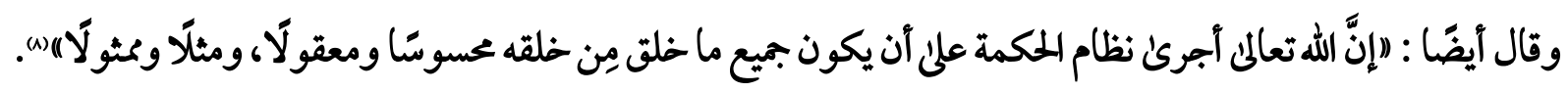

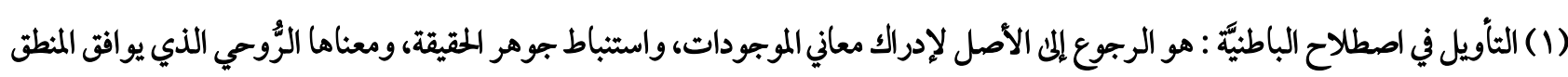

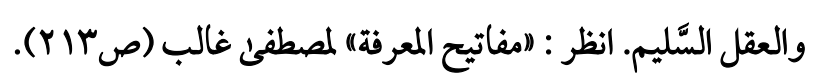

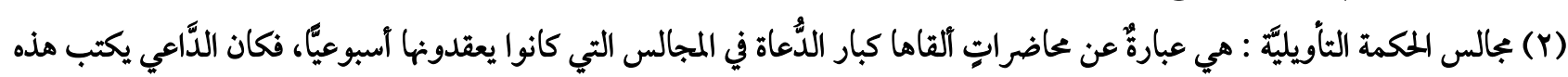

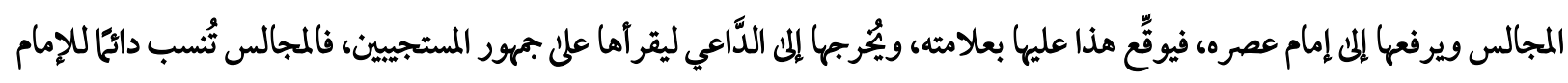

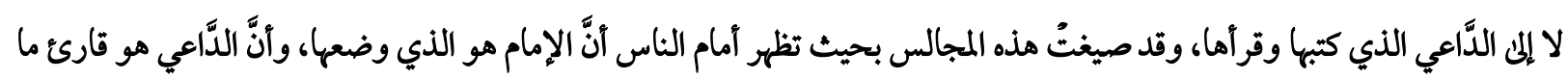

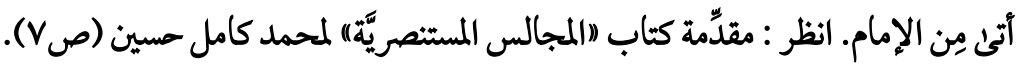

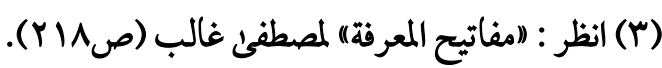

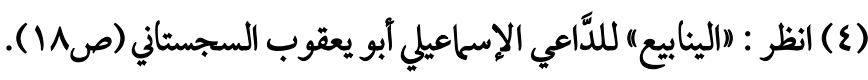

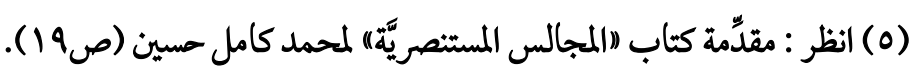

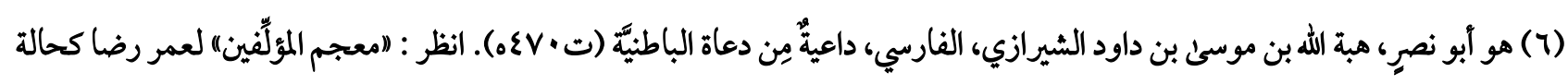

.) (1) $1 \varepsilon / / r)$

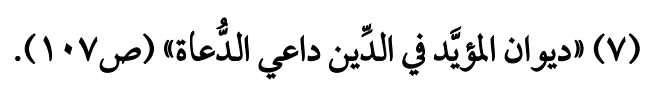

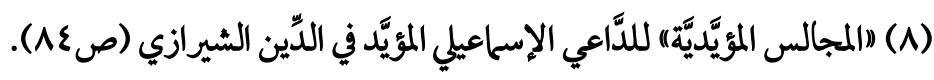




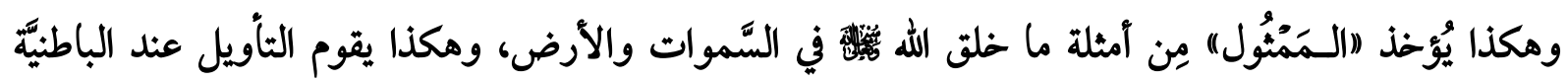
بالاستدلال بالمحسوسات على المعقولات")

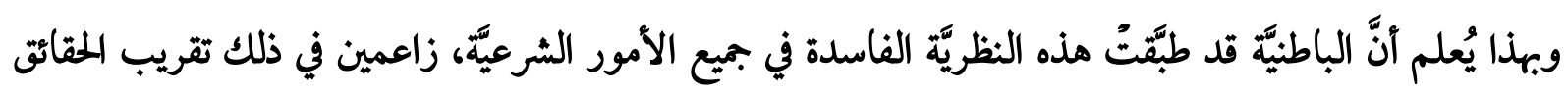

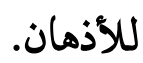

(1) انظر : مقدّمة كتاب (المجالس المستنصريَّة) لمحمد كامل حسين (ص ·Y). 


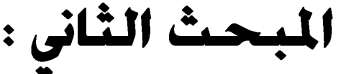

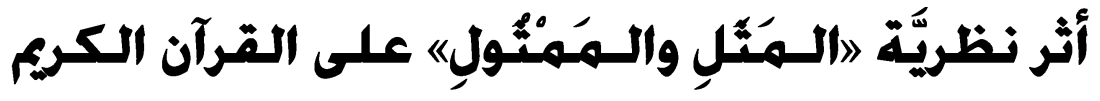

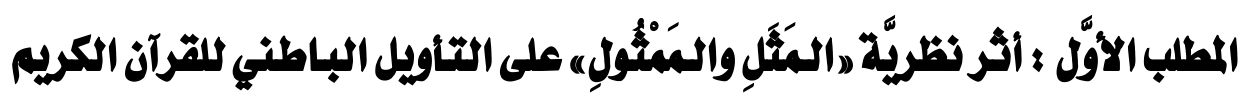

سلكت الباطنيَّة مسلك التأويل الفاسد للقرآن الكريم، وزعموا أنَّ مَن صار إلى تأويله الباطن فهو مِن الملائكة البررة،

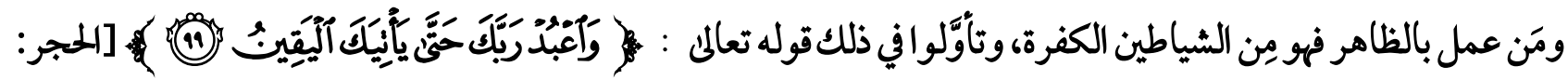
99 [9، ومملوا اليقين على معرفة التأويل (1).

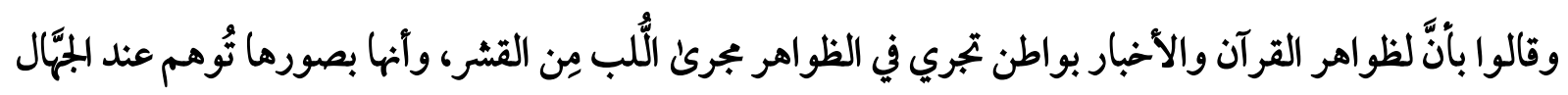

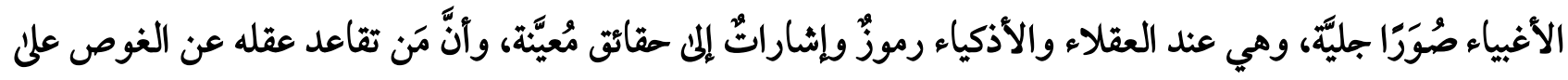

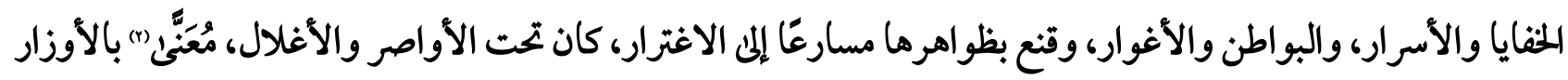

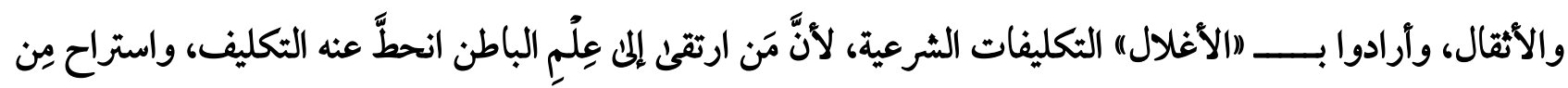

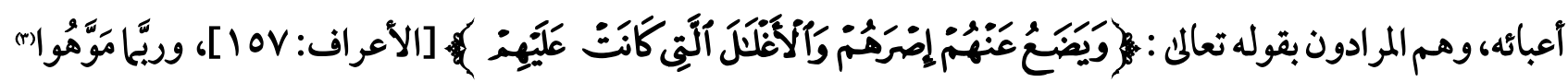

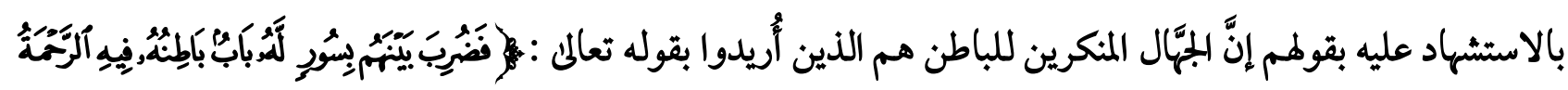

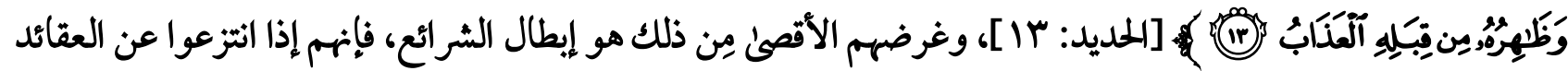

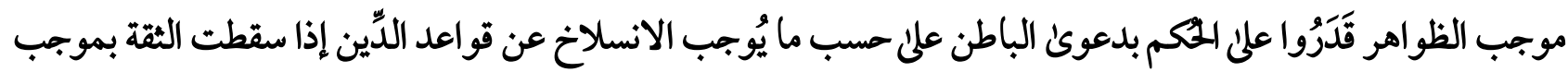

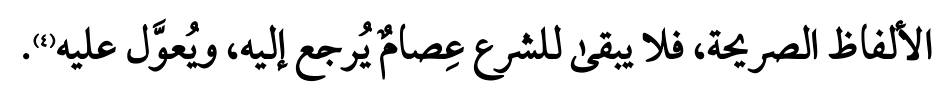

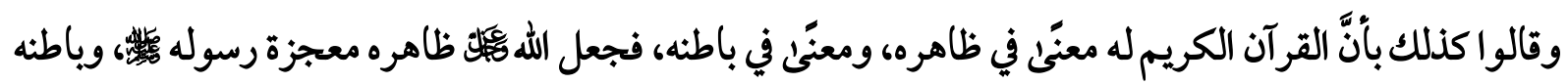

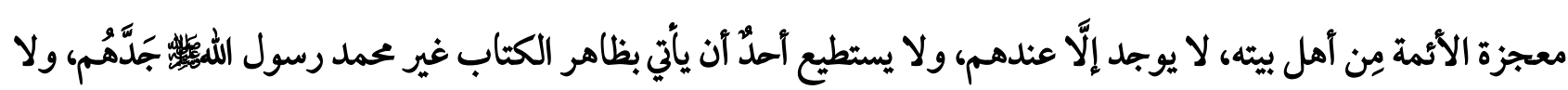

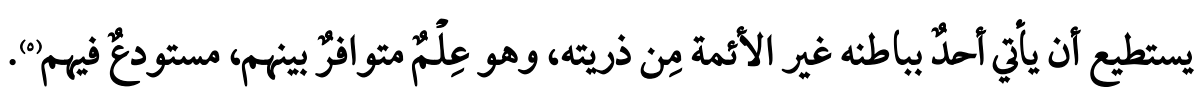

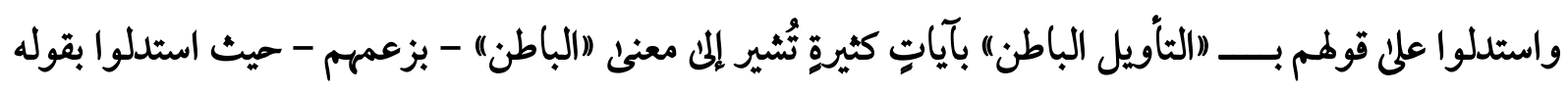

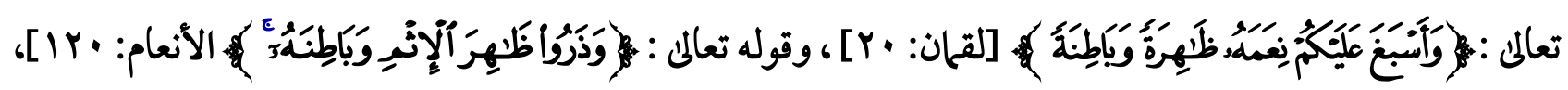

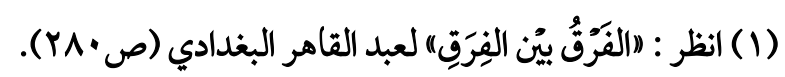

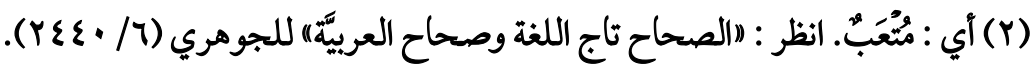

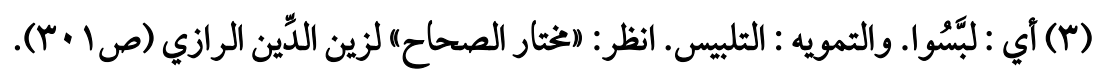

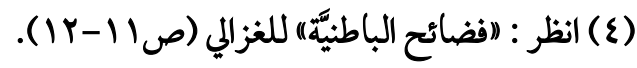

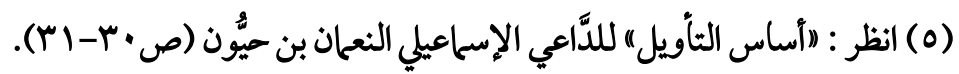




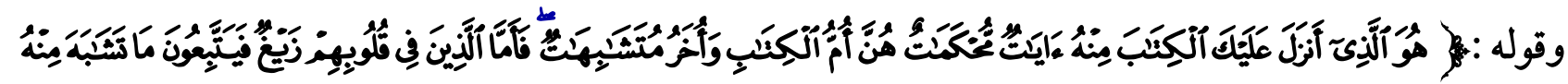

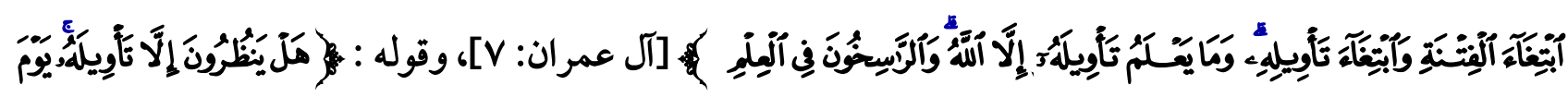

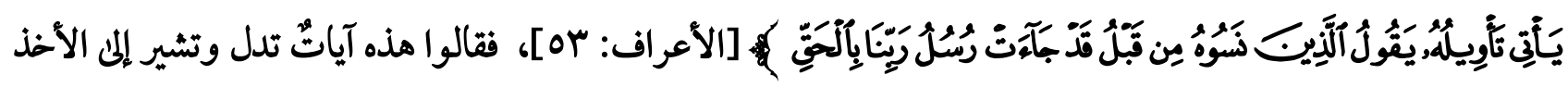
بــــ (التأويل الباطن" للقرآن الكريم").

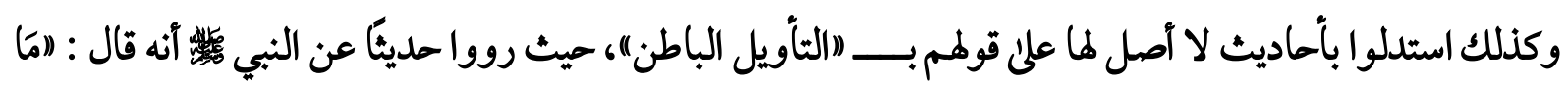

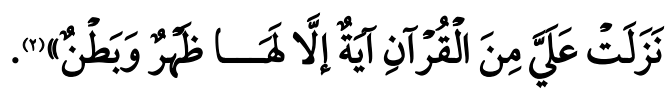

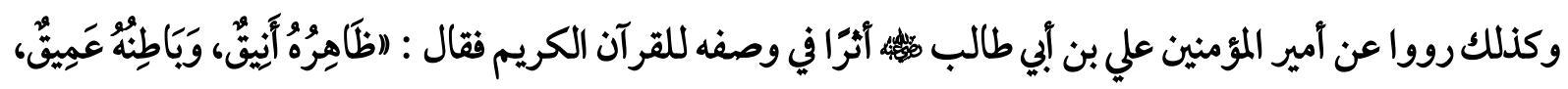

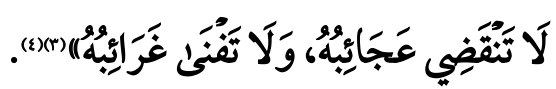

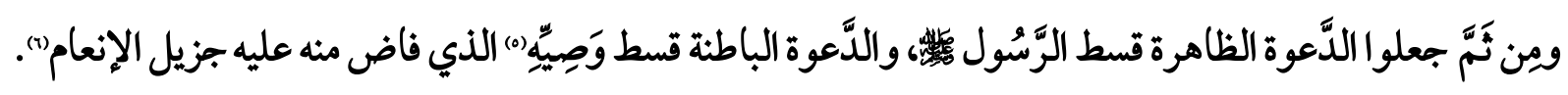

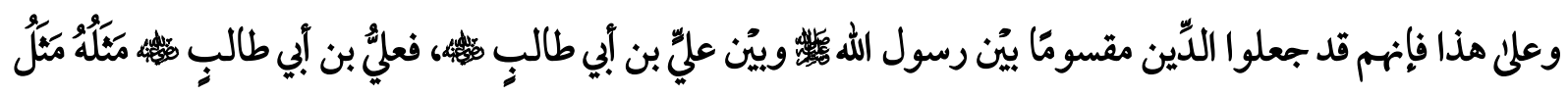

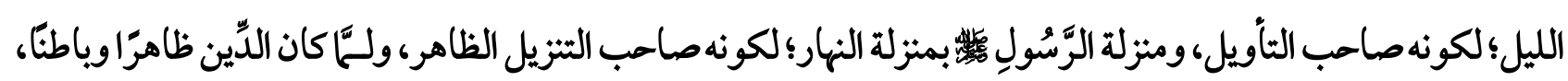

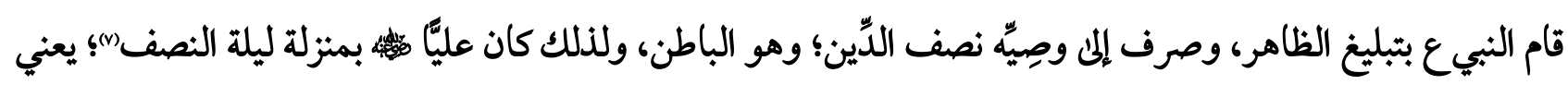
صاحب التأويل نس.

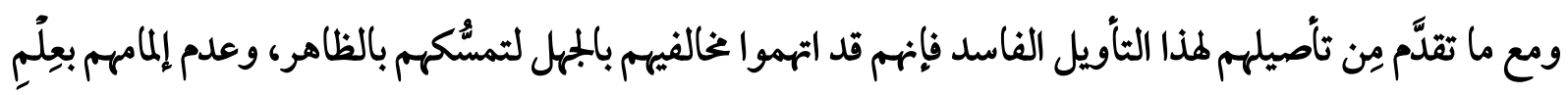

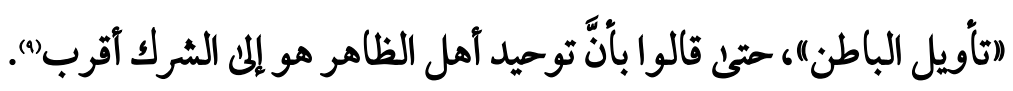

(1) انظر : (أساس التأويل) لللَّاعي الإسماعيلي النعان بن حيُّون (صه9 ).

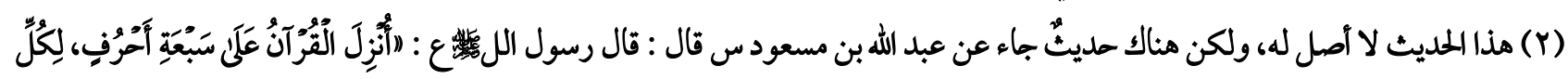

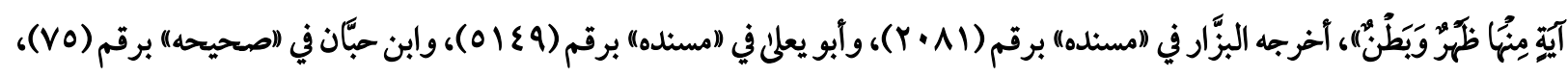

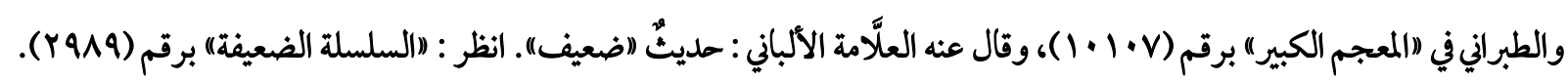

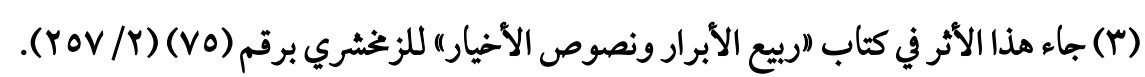

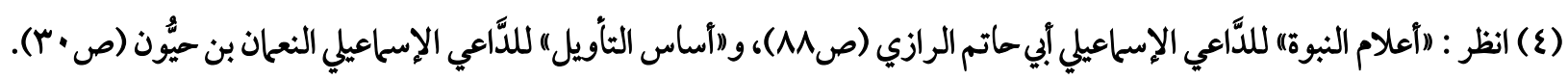

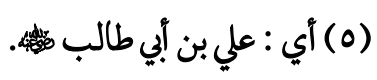

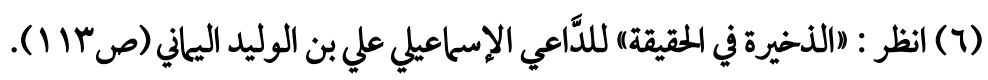

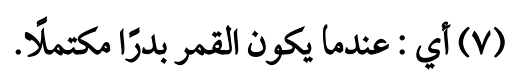

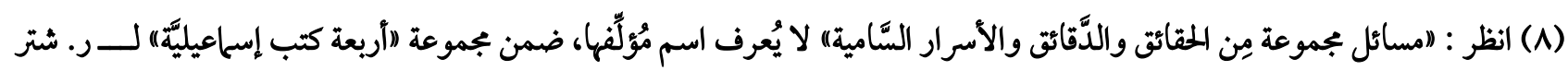
وطان (ص Or-זrr).

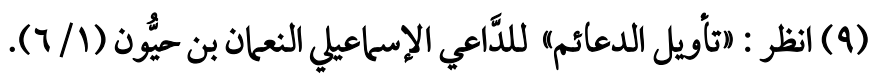


كا أنهم ذهبوا إلى تكفير غخالفيهم الذين يعملون بالظاهر دون الباطن، وقالوا : منكر صاحب التأويل كافرّ، وقالوا

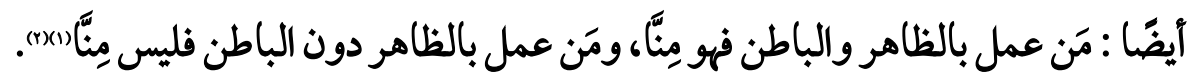

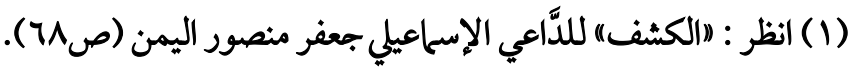

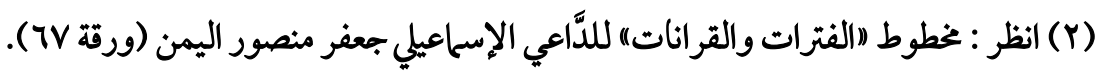




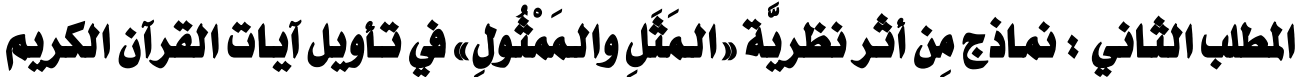

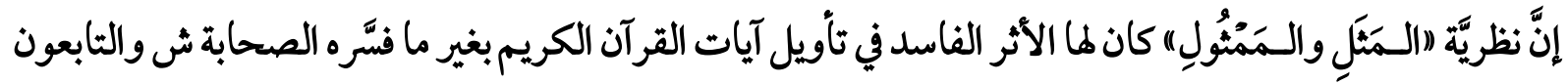
لمم بإحسان، ولقد جنحت الباطنيَّة إلى تفسير الآيات على ما يوافق أهواءهم، ويُمهِّد لهم السُّبل في تمرير عقائدهم الحبييثة مِن خلال هذه التأويلات الفاسدة - بزعمهم -. فمِن تلك الآيات التي فسَّروها استنادًا على هذه النظريَّة الفاسدة :

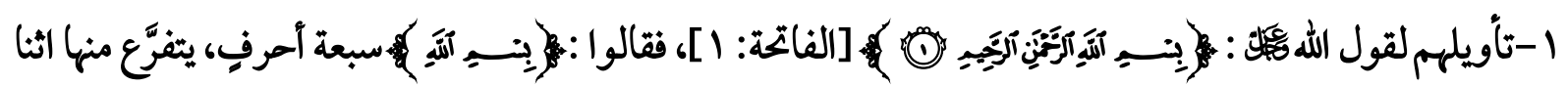

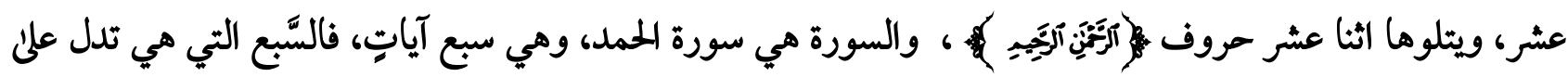

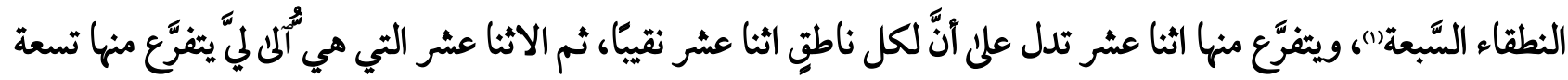

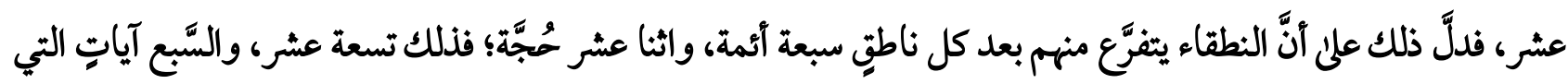

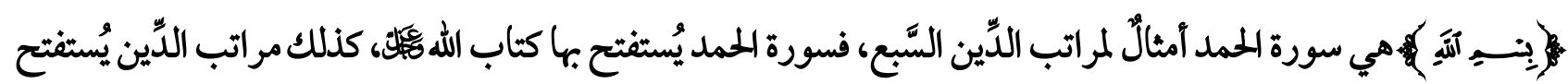

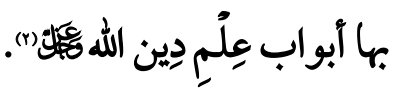

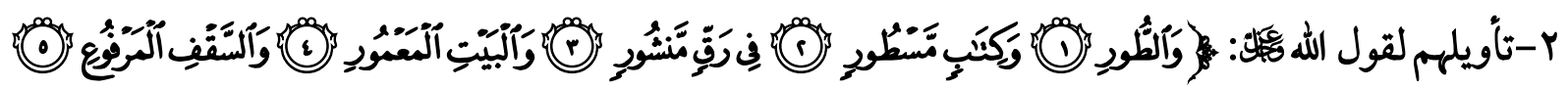

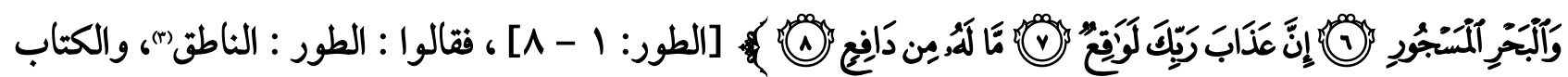

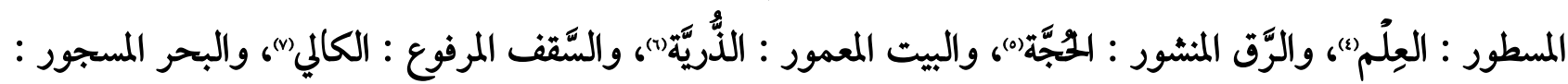

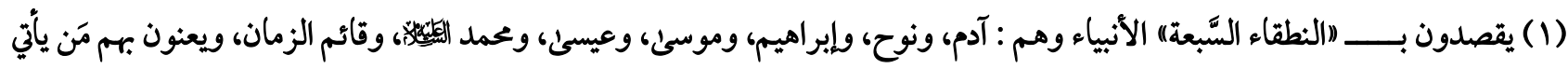

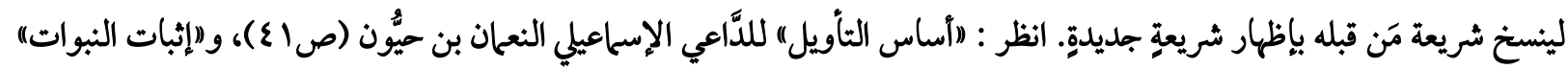

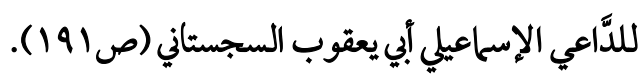

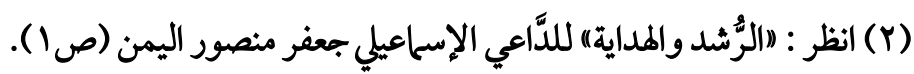

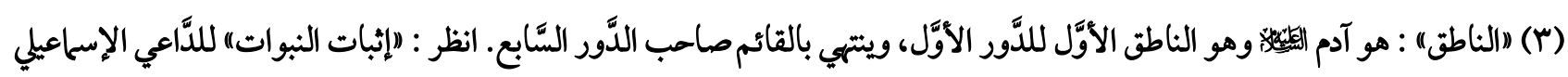

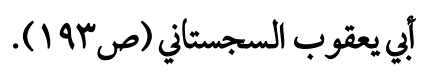

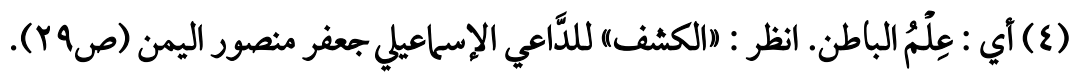

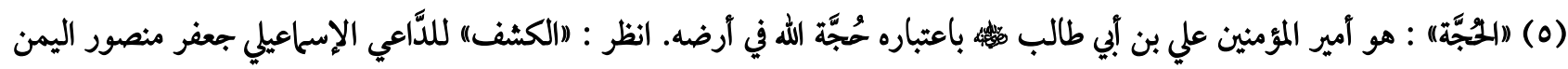

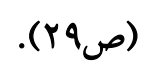

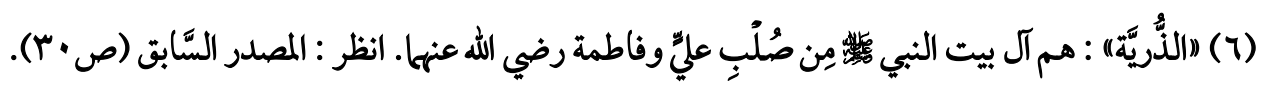

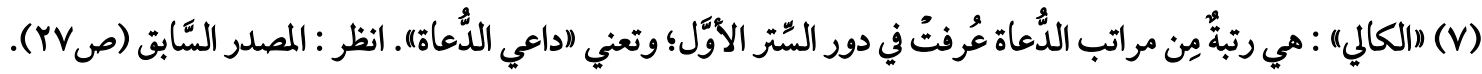


الباب"(1)، والعذاب الواقع : هو القائم"(1) الذي ما له مِن دافع".

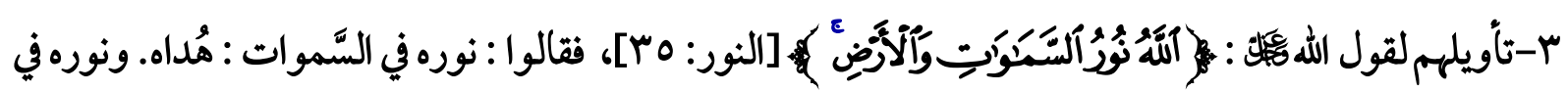
الأرض : الأئمة الذين يُهتدئ بهم).

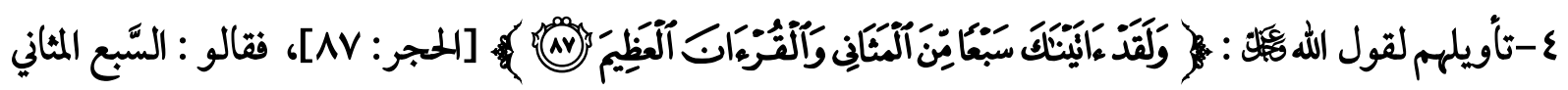

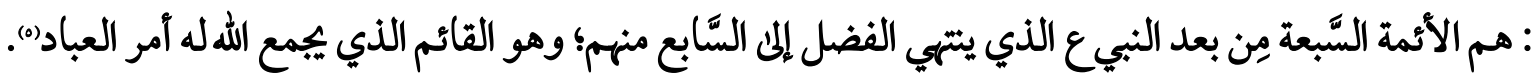

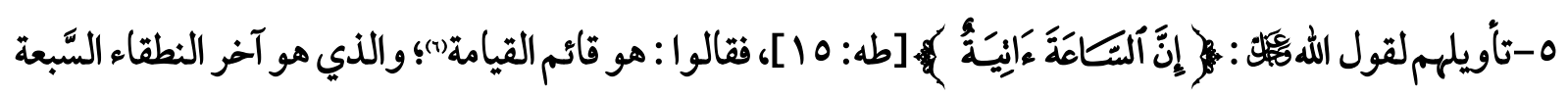
الذي يتتهي الدَّور إليههان.

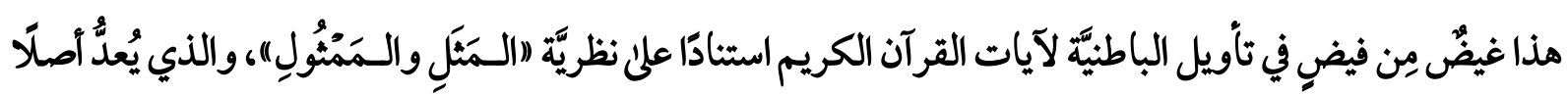

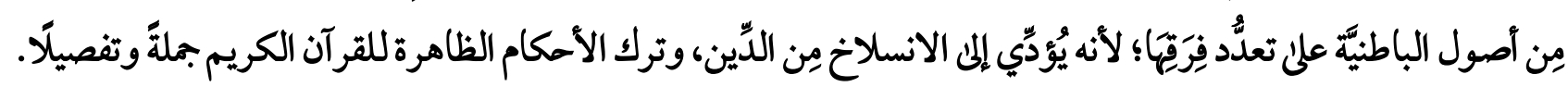

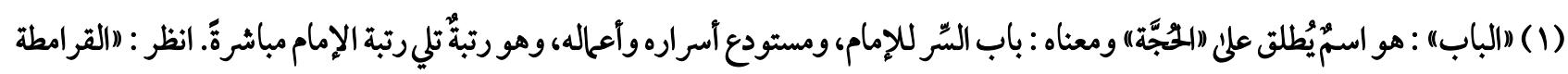

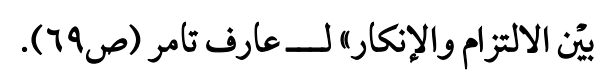

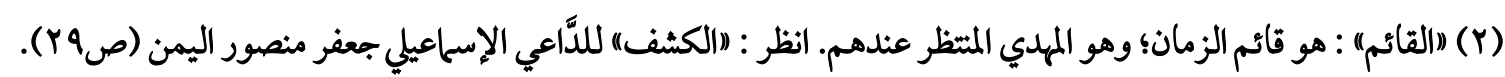

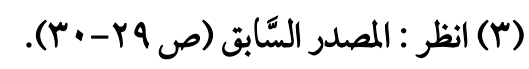

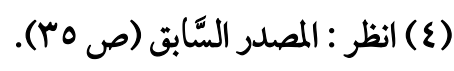

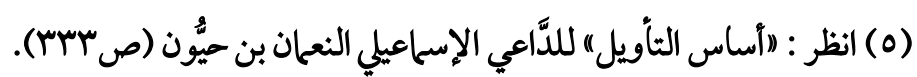

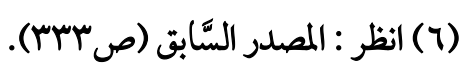

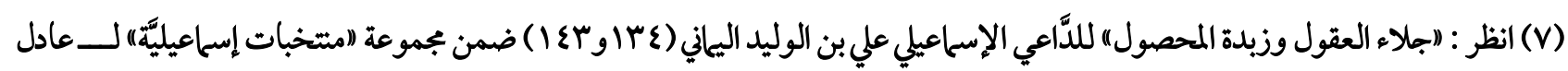


المبحث الثالث :

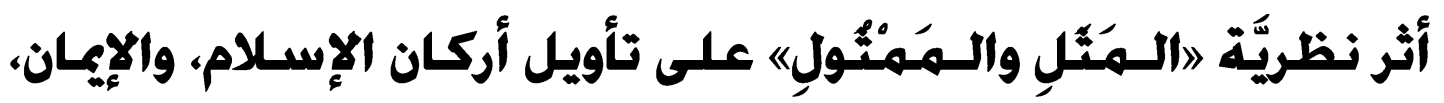

والشـريعة الإسـلاميَّة، ونقدها

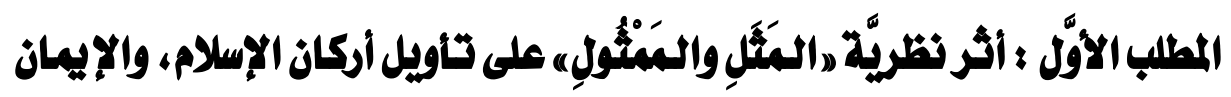

تأُوَّلت الباطنيّة كلَّ ركنِ مِن أركان الشريعة، تأويلَا يُورث تضليلَا، وزعموا أنَّ مَن عرف معنى العبادة سقط عنه

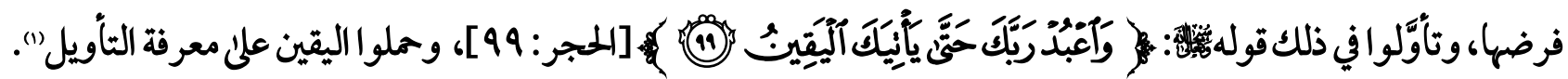
وفيا يأتي بيانٌ لبعض تأويلاتهم الفاسدة التي بنوها على أساس هذه النظريَّة الفاسدة.

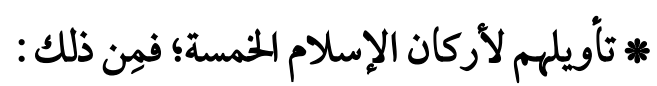

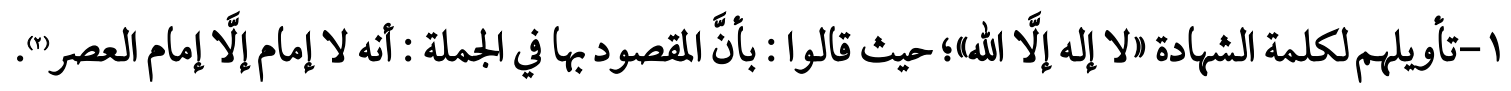

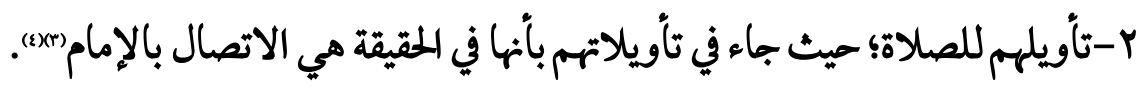

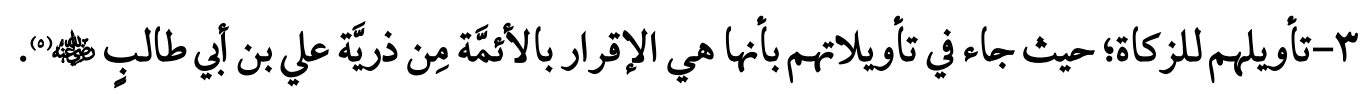

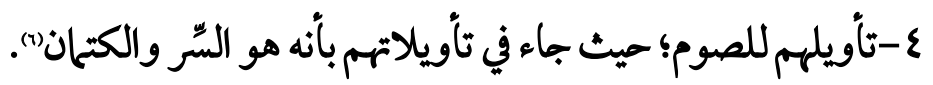

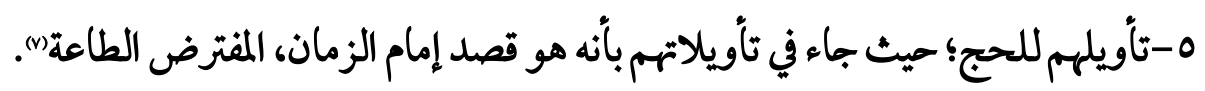

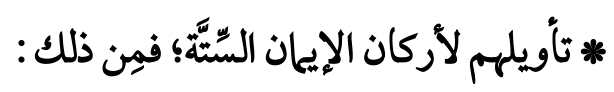

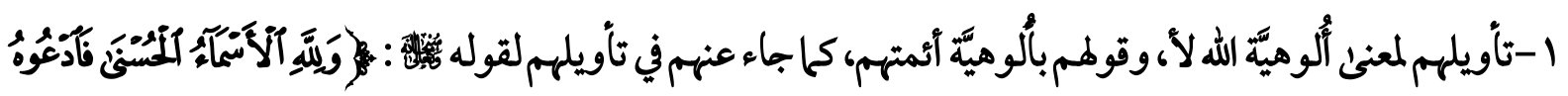

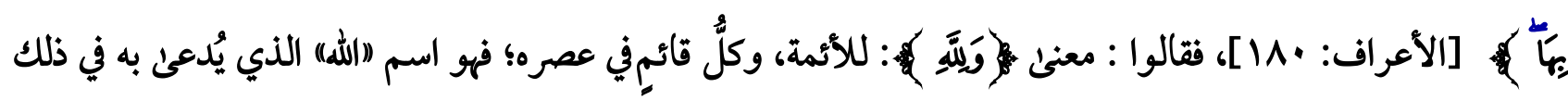
العصر (a)

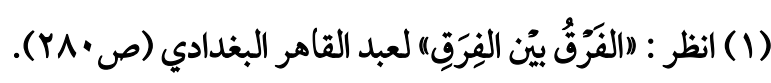

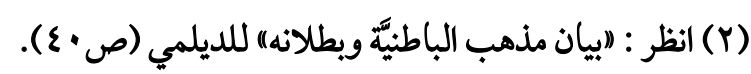

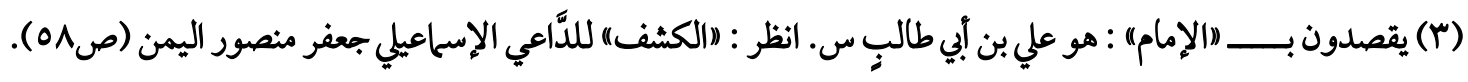

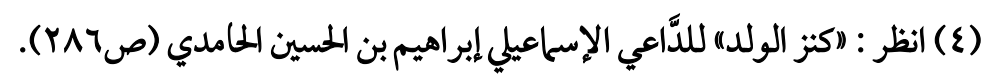

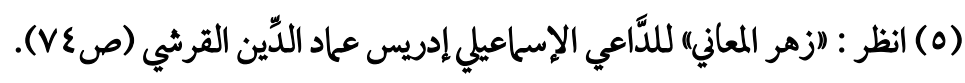

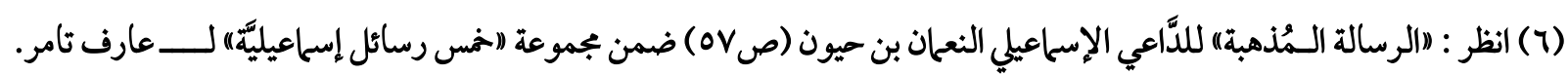

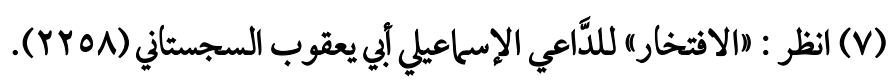

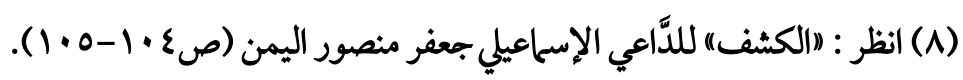




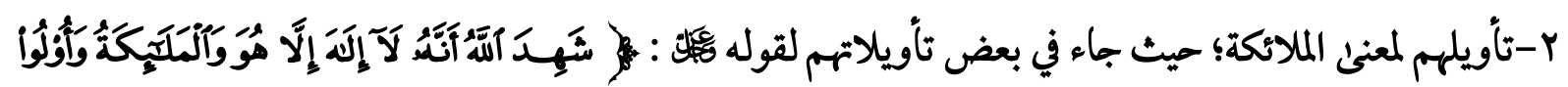

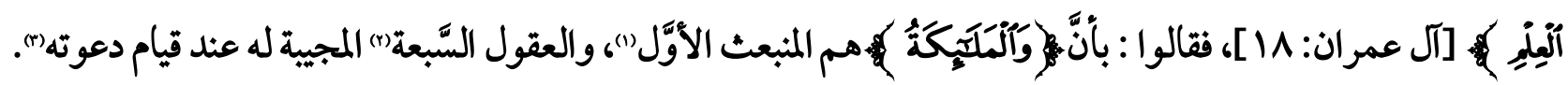

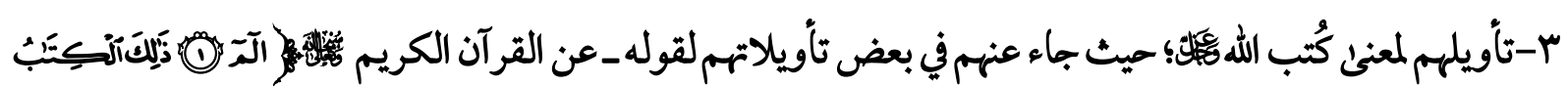

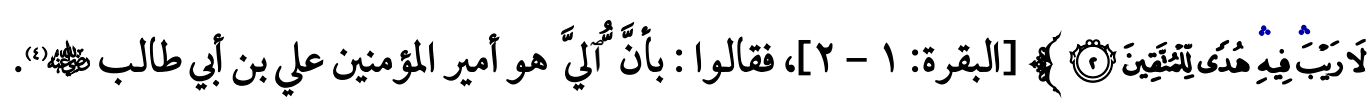

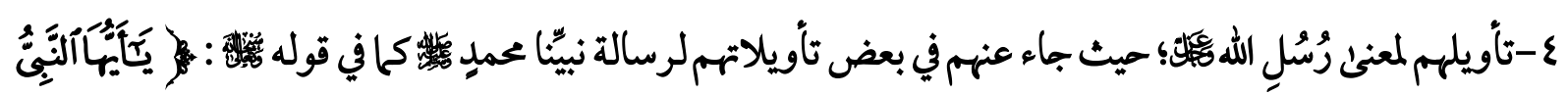

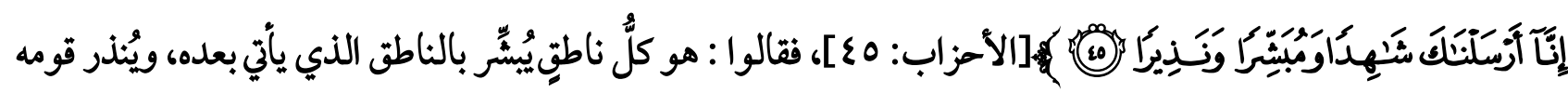
مِن أمة دورهم.ن.

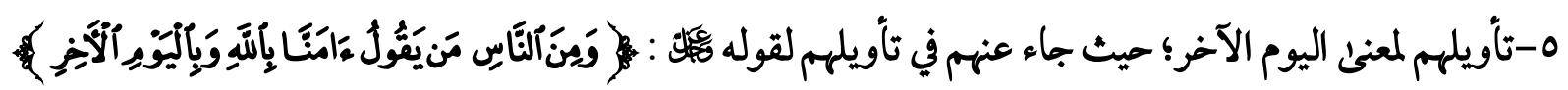

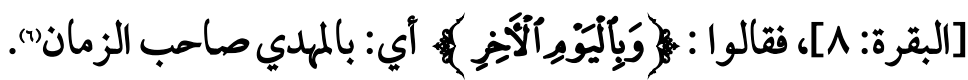

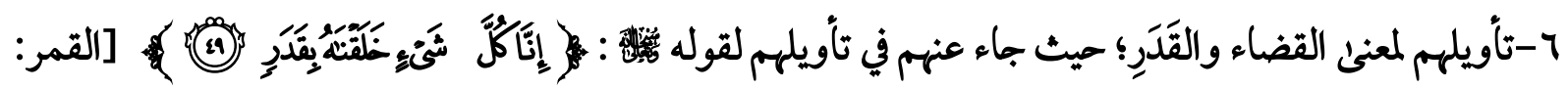

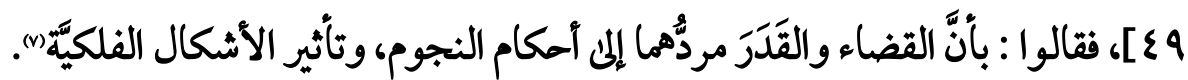

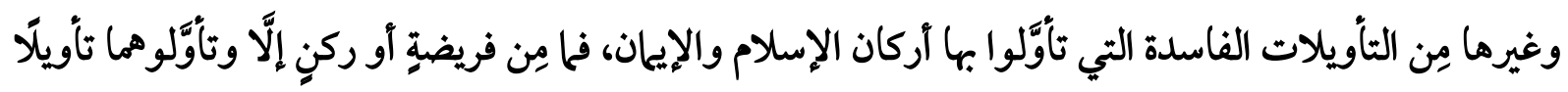
فاسدَا، يُرجرها عن حقيقتها الشرعيَّة.

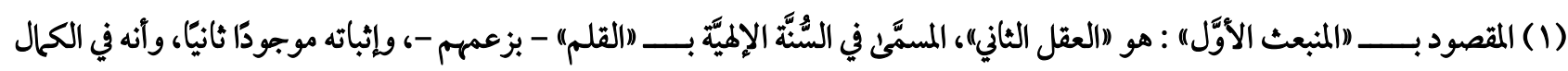

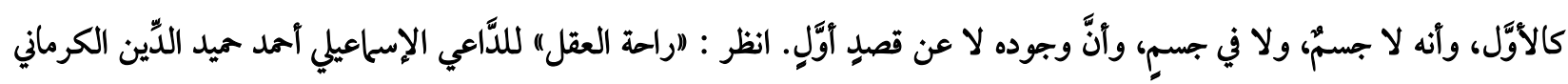
(ص) (r)

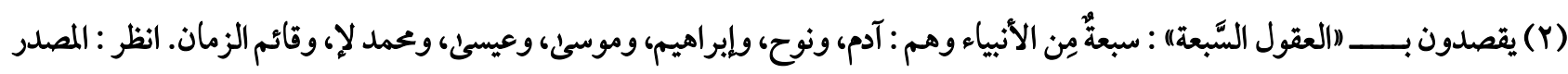

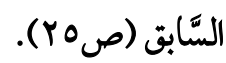

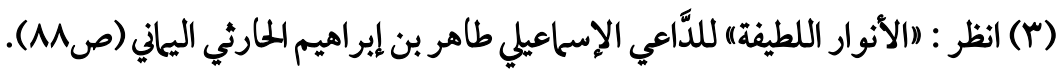

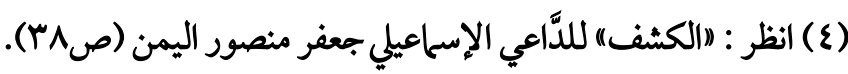

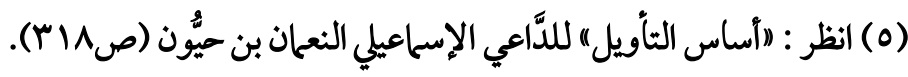

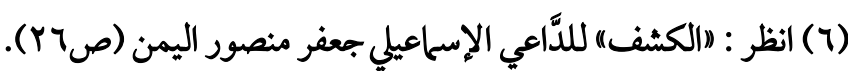

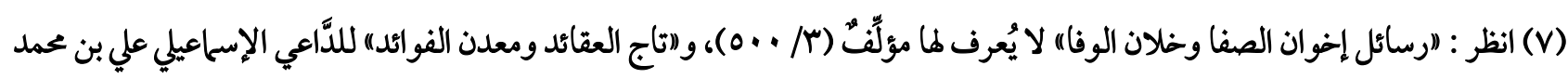

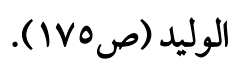




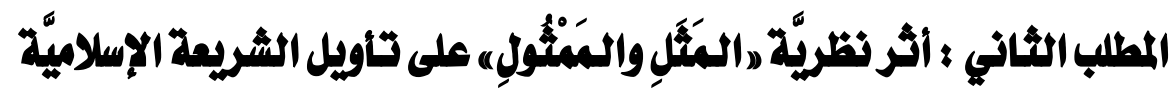

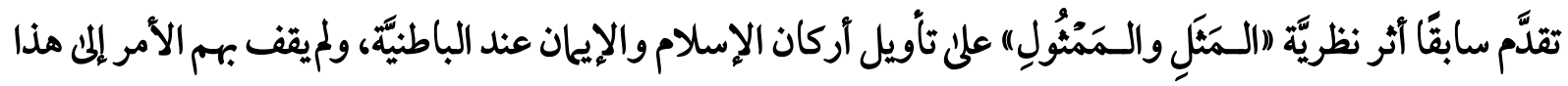
الحد؛ بل ذهبوا إلى تأويل الشريعة الإسلاميَّة بأكملها، وما جاء فيها مِن أمِِ ونهِي صرفوه عن حقيقته الشرعيَّة، وألبسوه لباس التأويل الفاسد استنادًا على هذه النظريَّة).

وقالوا : بأنَّ الحلال؛ هو الواجب إظهاره وإعلانه. والحرام؛ هو الواجب ستره وكتمانهها. كما أنهم حملوا اللفظ علي غير مسَّماه المعروف، بمجرد شبه بينها، مِن غير دلالةِ، بل ولا استعالِ لذلك اللفظ في ذلك المعنى الثاني في اللغة). (r).

وتأَُّّوا كلَّ آيات القرآن الكريم، وسُنَنِ النبيع على موافقة أساسهم في التأويل الباطني (8).

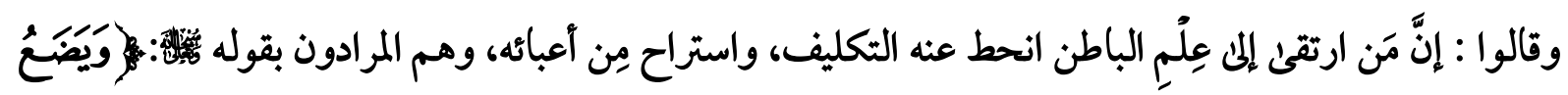

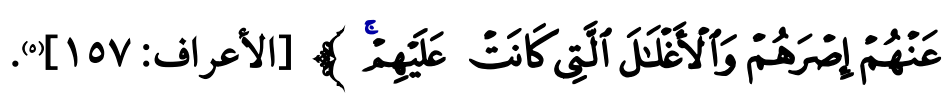

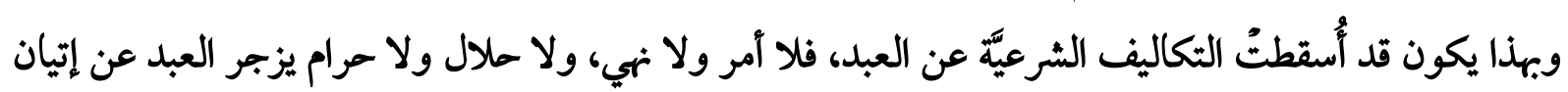

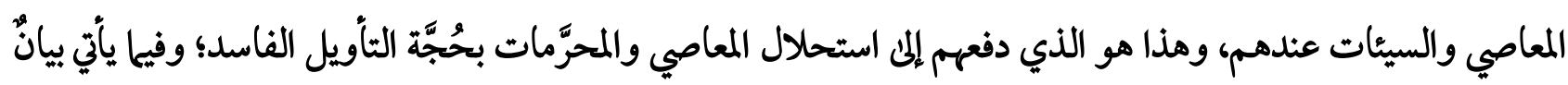

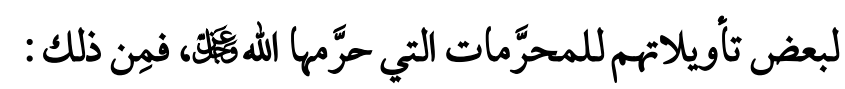

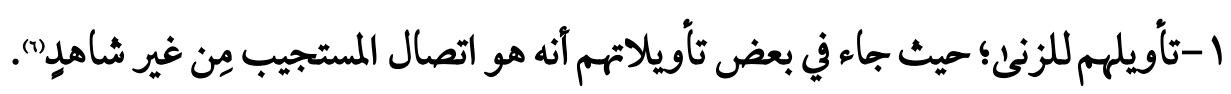

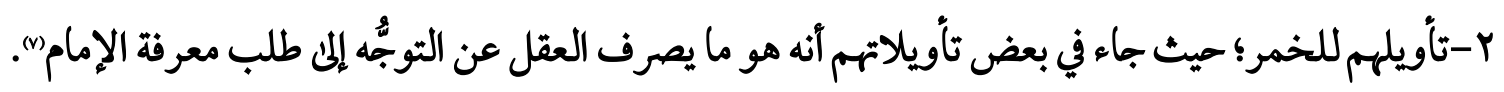

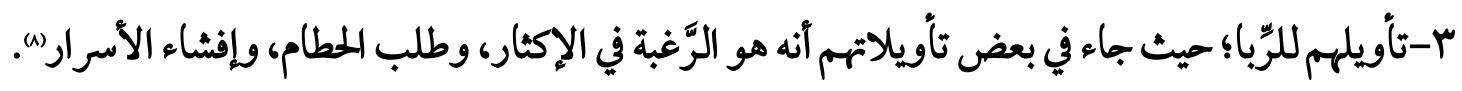

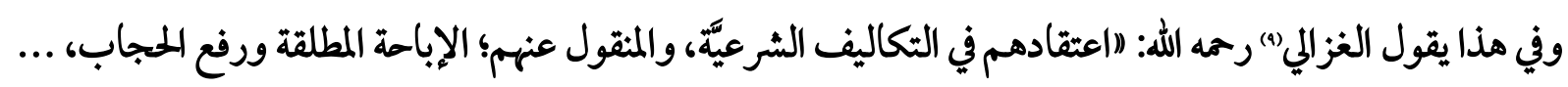

$$
\text { (1) انظر : (بيان مذهب الباطنيَّة وبطلانه) للديلمي (ص • ع). }
$$

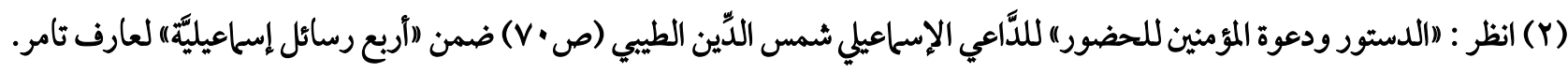

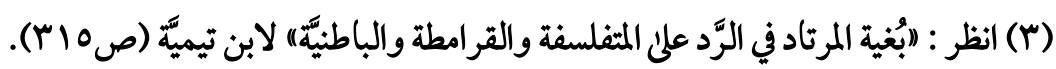

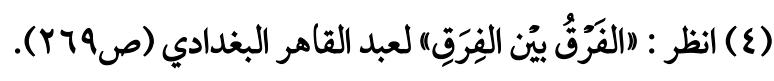

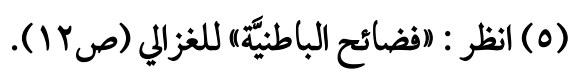

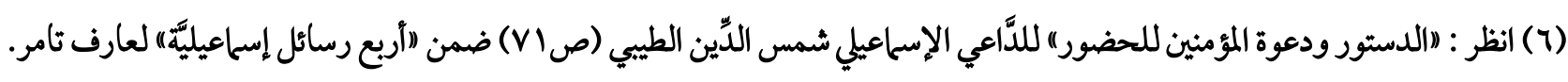

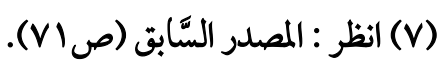

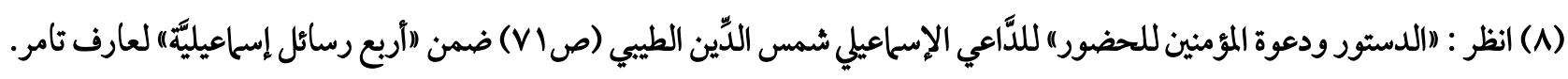

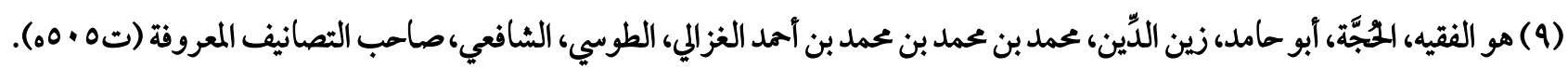


ويقولون لا بدمِن الانقيادللشرع في تكاليفه على التفصيل الذي يُقصّّله الإمام، ... فإذا أحاطوا مِن جهة الإمام بحقائق الأمور واطظّلعوا على بواطن هذه الظواهر انحلَّتُ عنهم هذه القيود، وانحطَّتُ عنهم هذه التكاليف العَمَلِيَّة) (1).

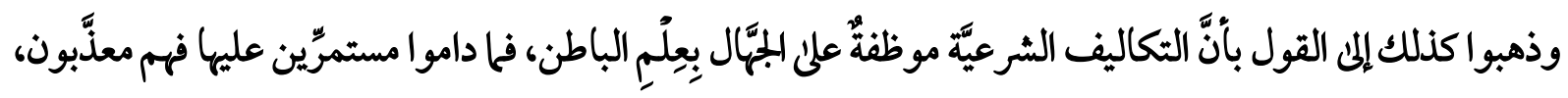

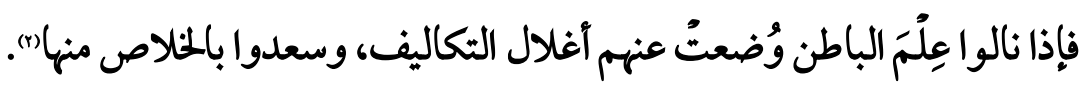

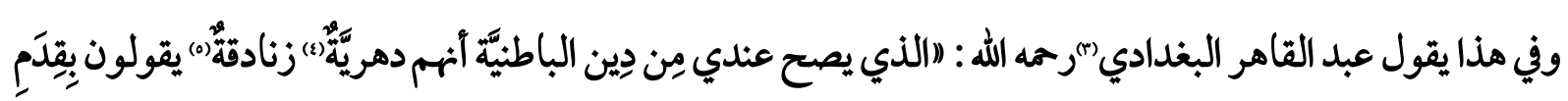

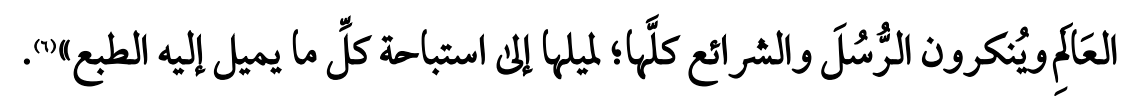

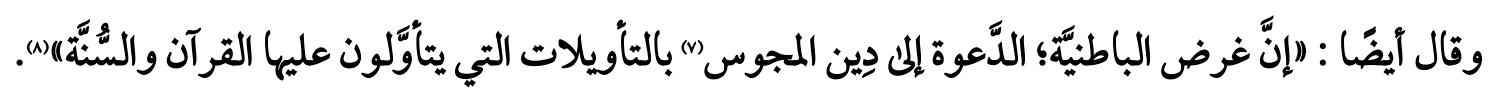

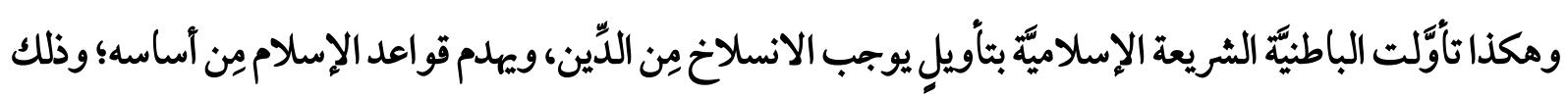
استنادًا واعتمادًا علئ هذه النظريَّة الفاسدة الكاسدة.

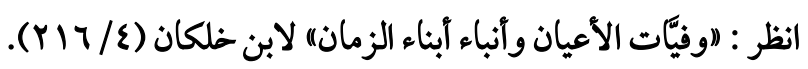

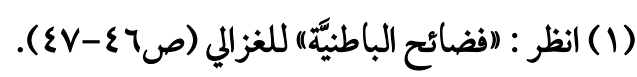

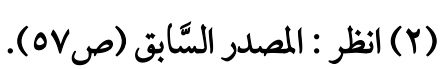

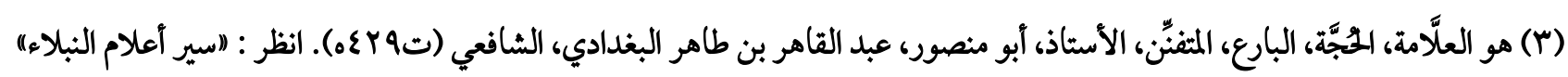

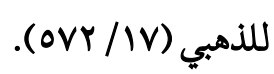

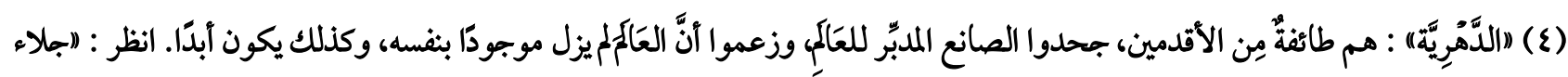

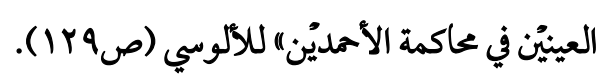

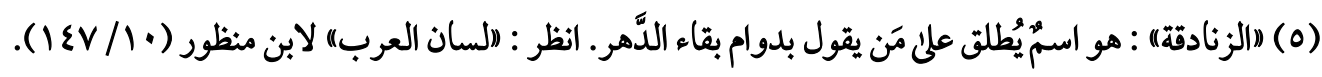

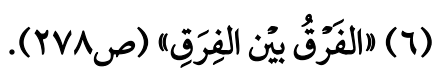

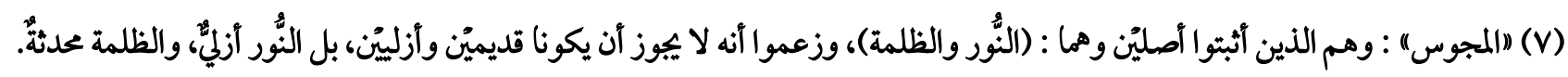

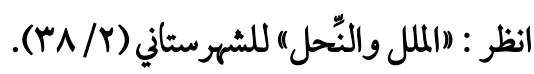

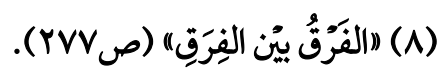




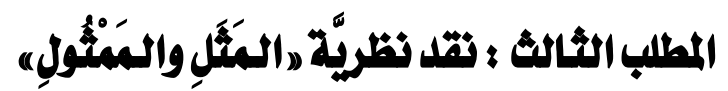

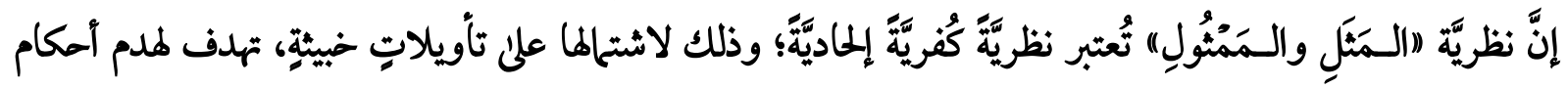

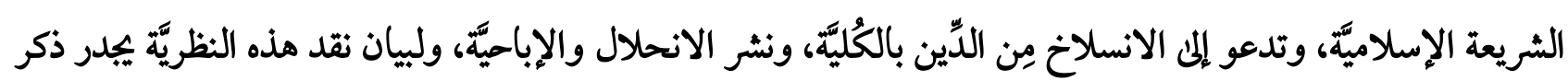
بعض أقوال أهل الِعلْم في بيان حقيقتها، وما آلتّ إليه مِن التأويل الفاسد.

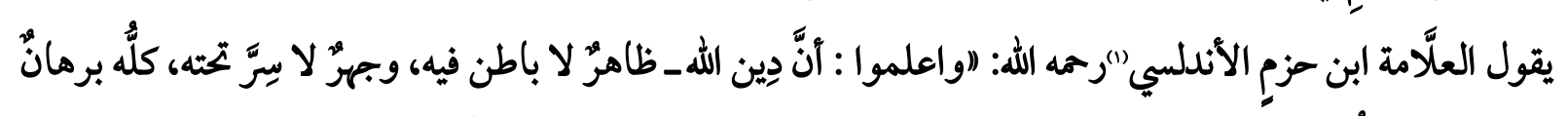

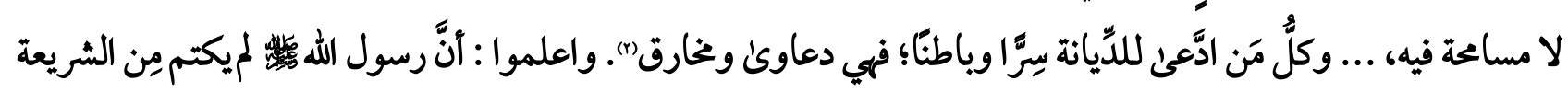

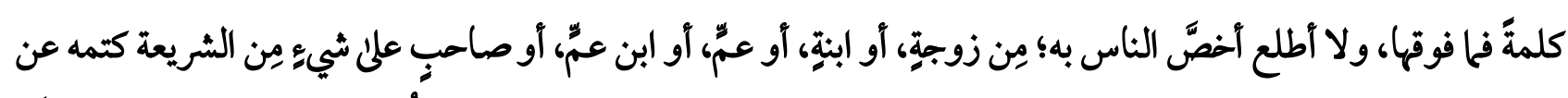

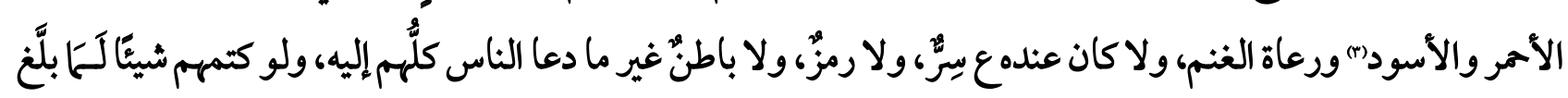

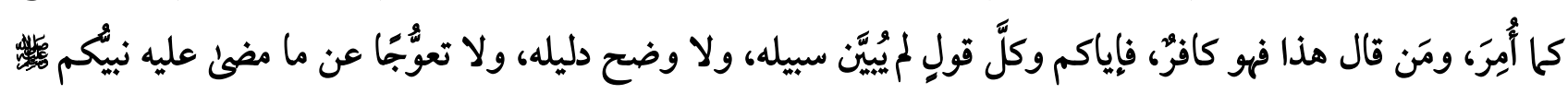
وأصحابه

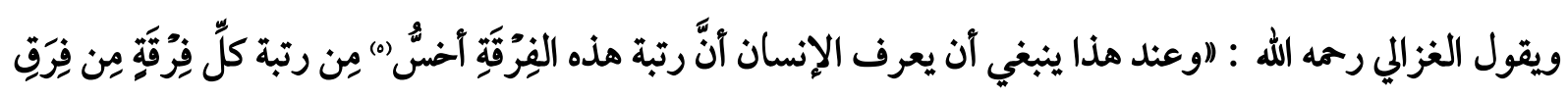

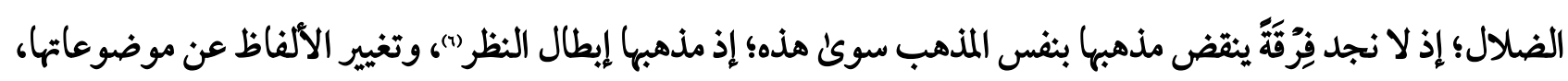

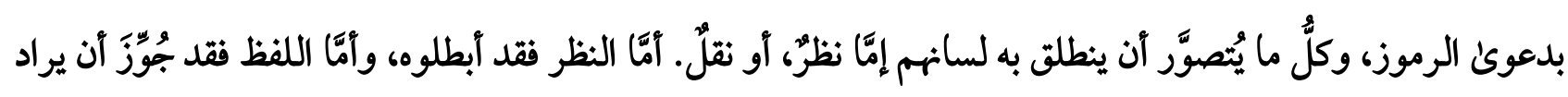
باللفظ غير موضوعه، فلا يبقى لهم معتصمّم) (1).

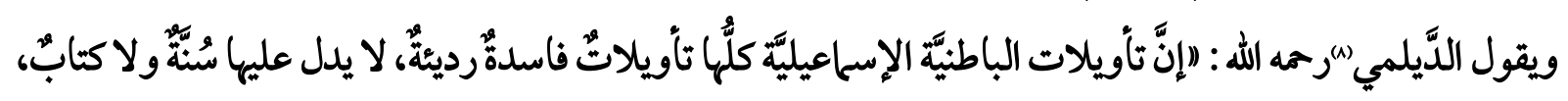

(1) هو العلًامة، الفقيه، البحر، ذو الفنون والمعارف، أبو محمد، علي بن أمد بن سعيد بن حزمِ، الفارسي الأصل، ثم الأندلسي، القرطبي، صاحب

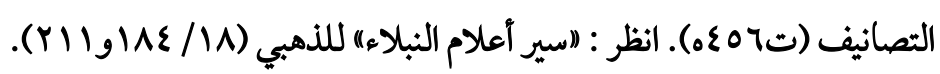

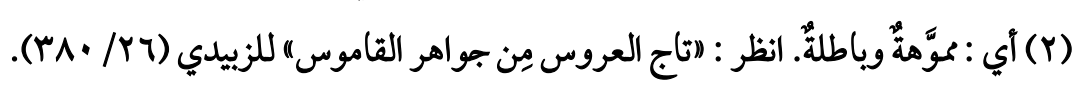

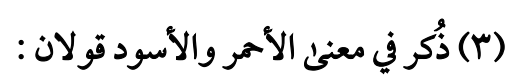

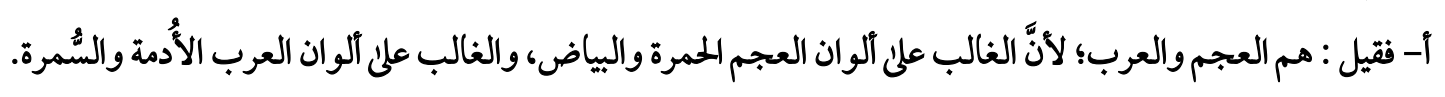

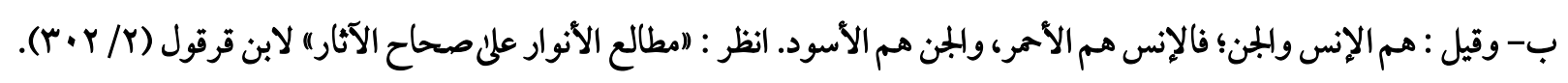

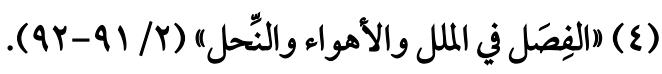

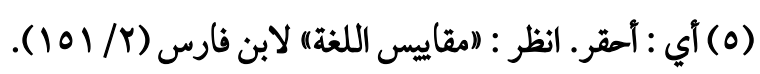

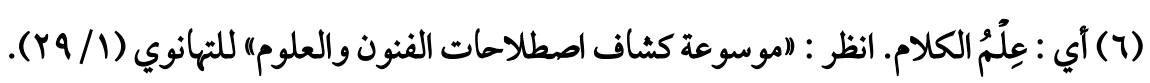

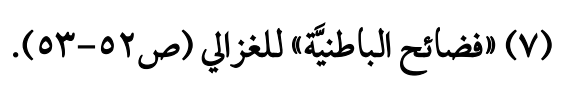

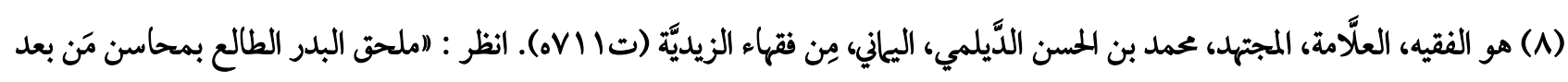

$$
\text { القرن السّابع" لمحمد زبارة المسني (Y/ ع 19). }
$$


وهي باطلةٌ عند أولي الألباب، خارجةٌ عن الحقّ والصواب)|(1).

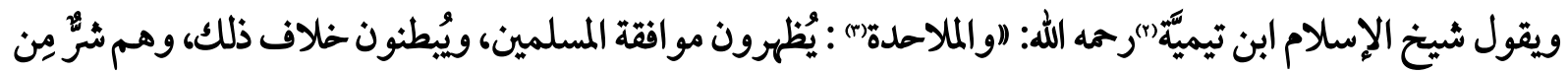

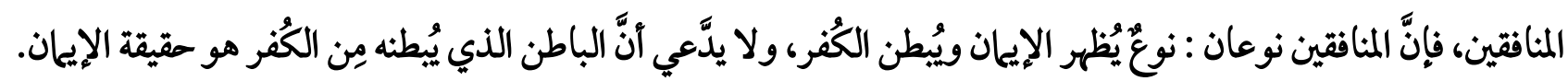

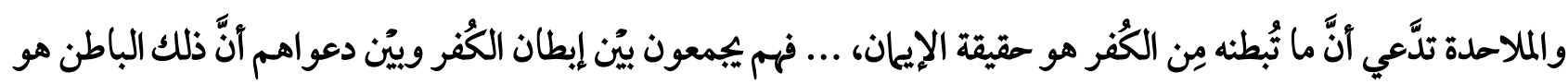

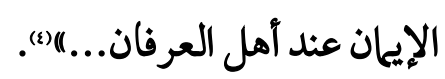

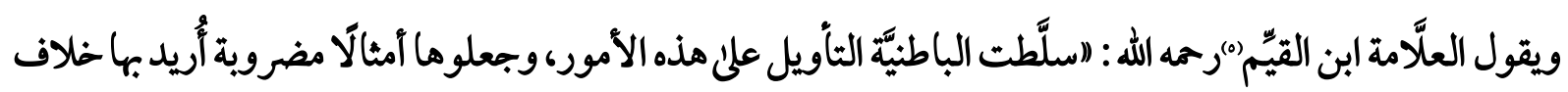

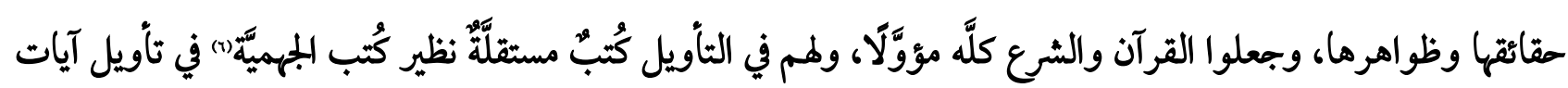

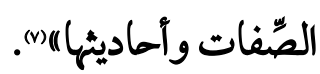

وبعد سرد هذه النقول يتبيَّن بجلاءِ فساد هذه النظريَّة النكراء، وما تحمله مِن تأويلِ فاسِِ لأمكام الشريعة الإسلاميَّة،

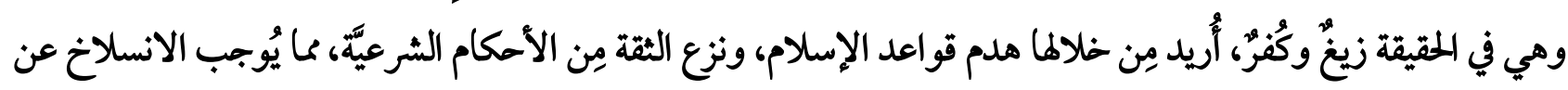
قواعد الدّيّن، ويُمهِّد لمم تمرير عقائدهم الكُفريَّة، وآراءهم الإلماديَّة.

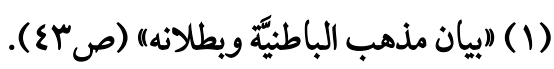

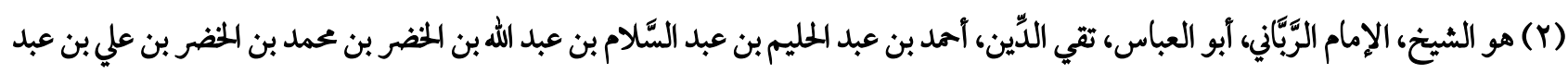

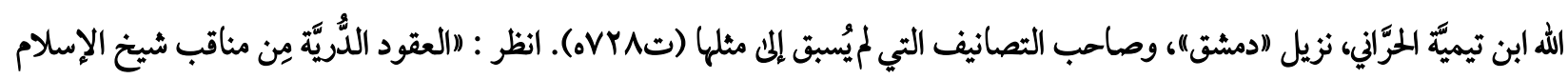

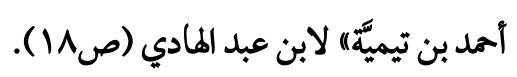

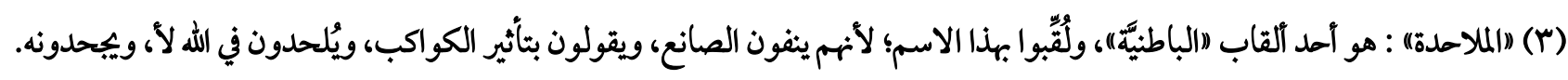

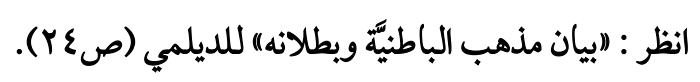

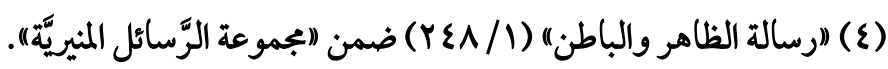

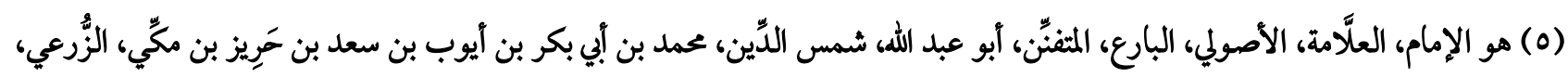

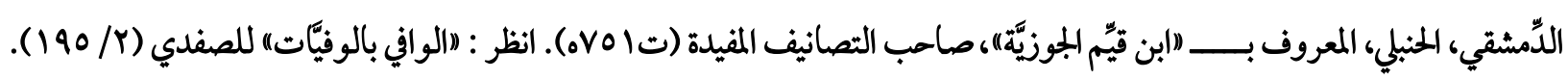

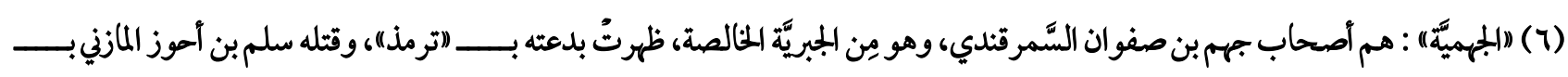

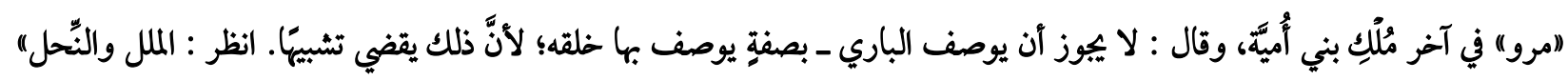

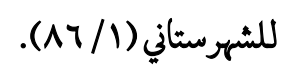

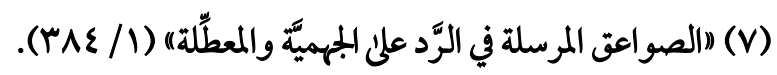




\section{الخاتمـة :}

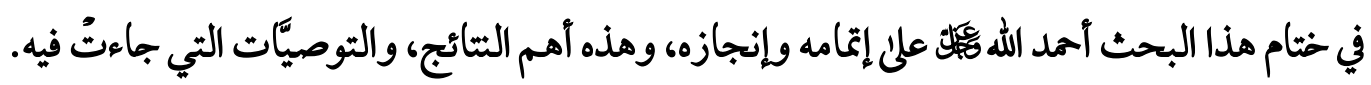
أوكَثًا : النتائج.

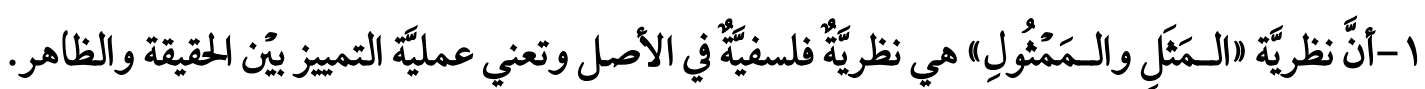
r- بأنَّ أوَّل مَن قال بهذه النظريَّة هو الفيلسوف اليوناني أفلاطون. ب-أنَّ هذه النظريَّة دخلتُ على بلاد المسلمين في عهد الحلافة العباسيَّة في زمن الخليفة المأمون العباسي. ع-تُعتبر هذه النظريَّة هي قاعدة التأويل، والركن الركين الذي تعتمد علئ عليه الباطنيَّة في جميع تأويلاتها.

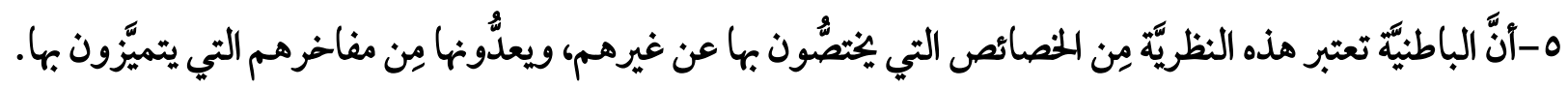

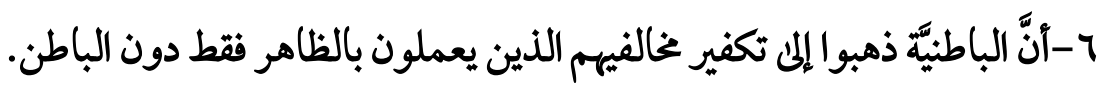

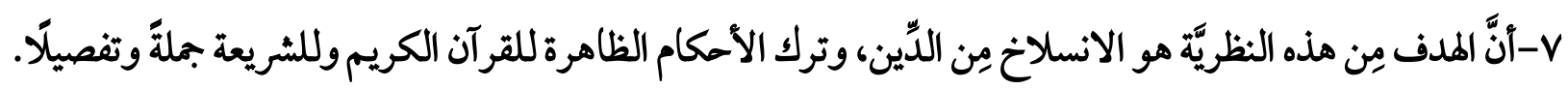
ثانيا : التوصيسّات.

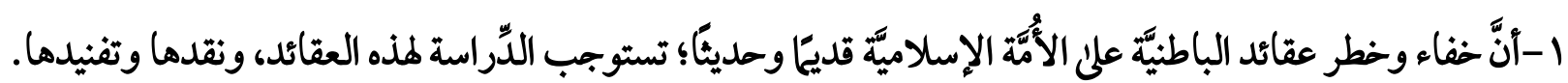

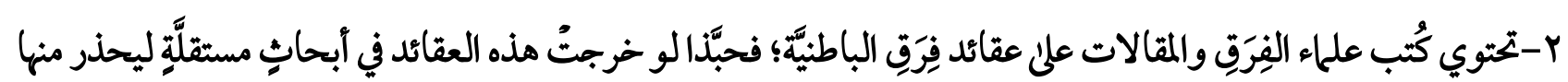
المسلمون.

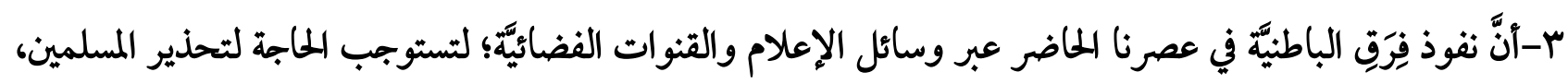

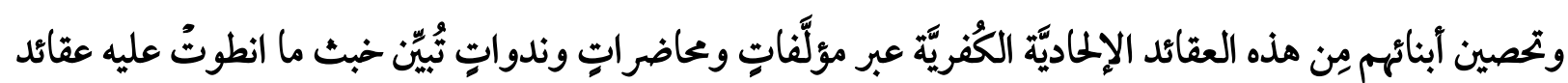

الباطنيَّة.

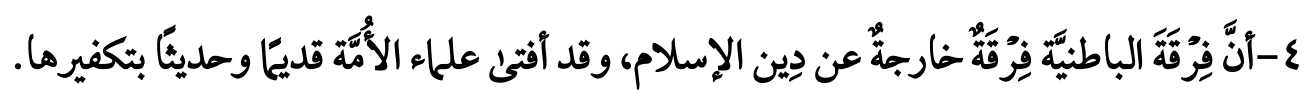




\section{المصسادروالمراجع}

1-القرآن الكريم.

Y-(اصحيح مسلم = المسند الصحيح المختصر مِن السُنَِّ بنقل العدل عن العدل عن رسول الله

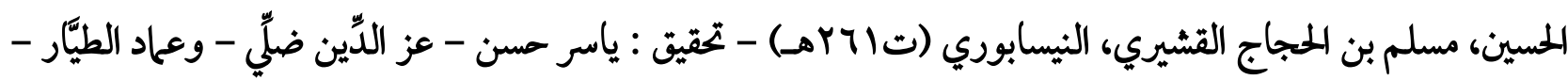

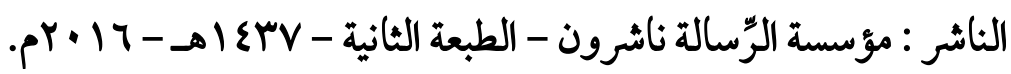

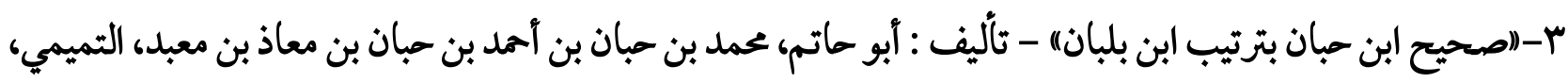

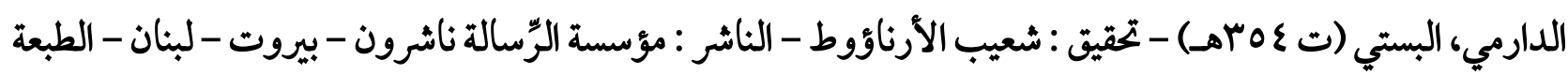

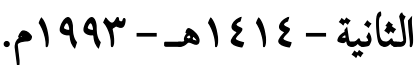

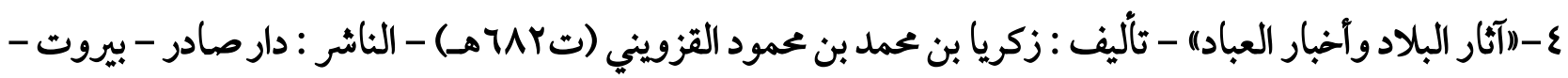
لبنان. ه-(إنبات النبوات) - تأليف : الدَّاعي الإسماعيلي أبو يعقوب، إسحاق السجستاني (ت (آبهـ) - تحقيق : عارف تامر الناشر : دار المشرق - بيروت - لبنان - الطبعة الثانية. 1-("أساس التأويل) - تأليف : الدَّاعي الإسماعيلي النعان بن حيون التميمي المغري (ت بآسهـ) - تحقيق : عارف تامر الناشر : منشورات دار الثقافة - بيروت - لبنان.

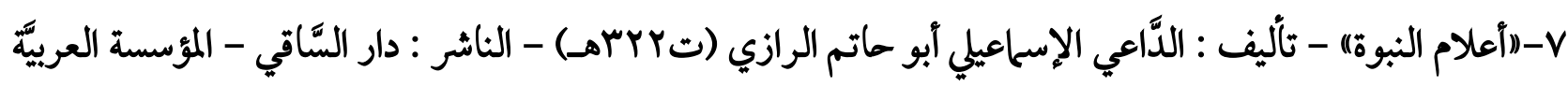

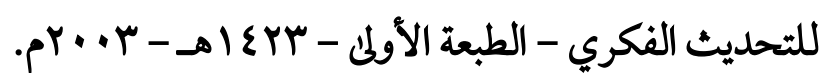

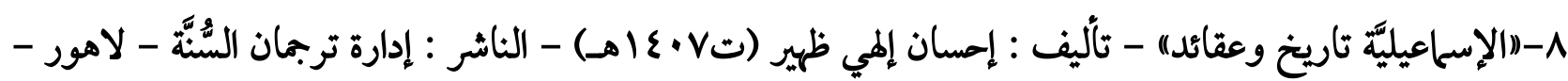
باكستان.

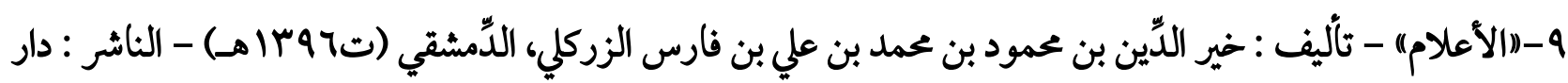

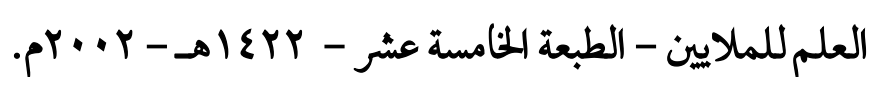

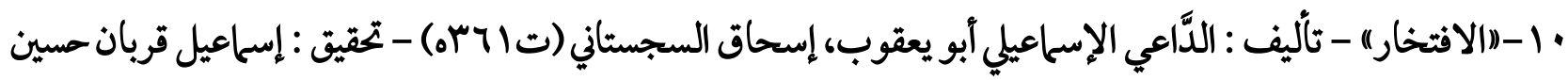

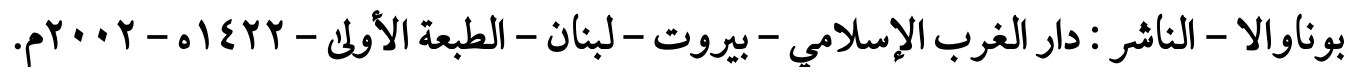

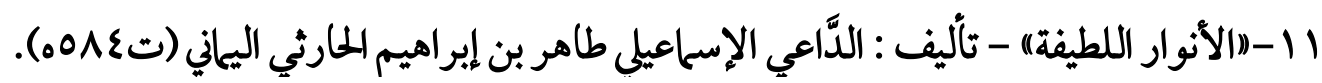

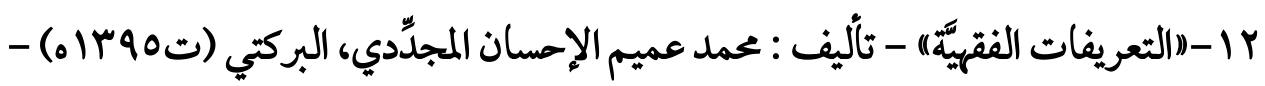

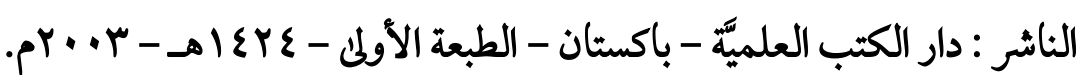

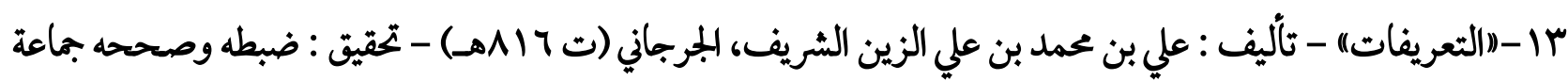

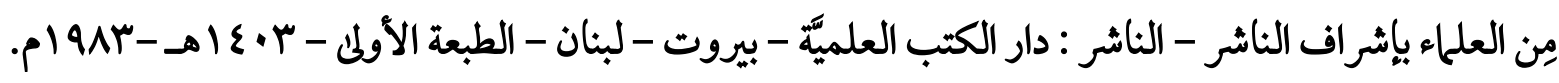


ع ا-("الجاسوس على القاموس) - تأليف : أحمد فارس بن يوسف الشدياق (تع +rاه) - الناشر : مطبعة الجوائب -

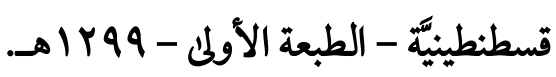

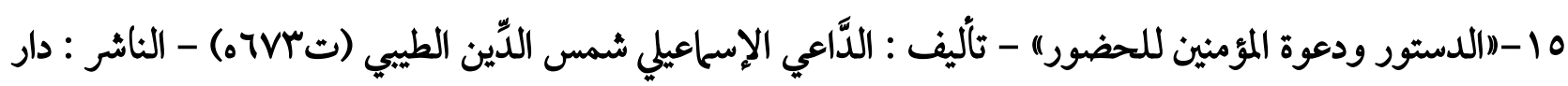
مكتبة الحياة - بيروت - لبنان - الطبعة الأولى - $19 \vee 1$ ام.

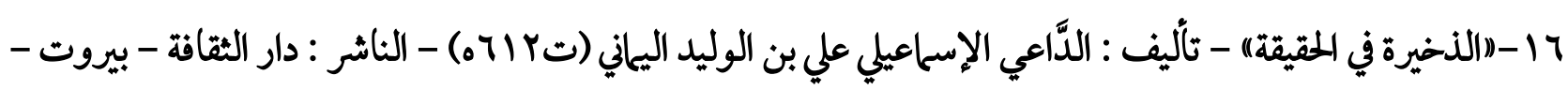

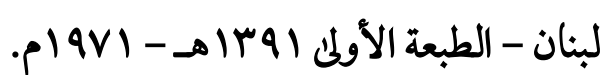

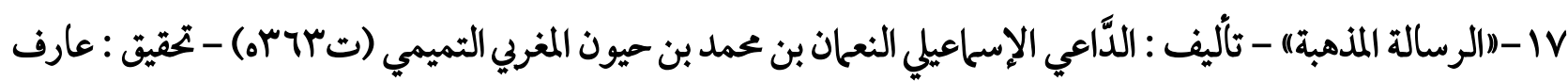
تامر - الناشر : دار الإنصاف للتأليف والطباعة والنشر - دمشق - سوريا - الطبعة الأولى - 1907 ام.

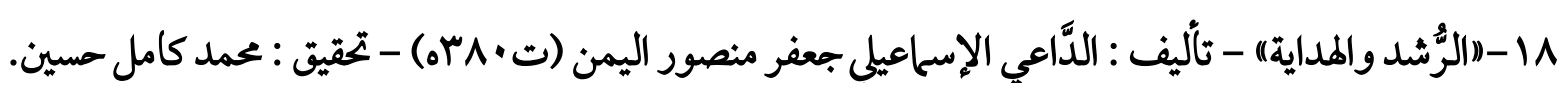

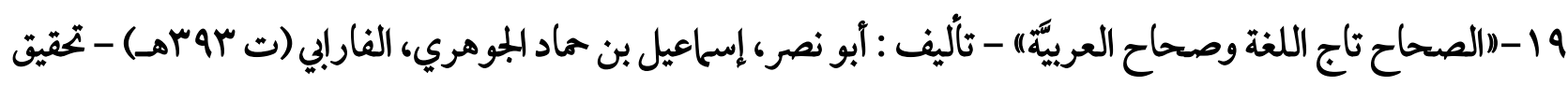

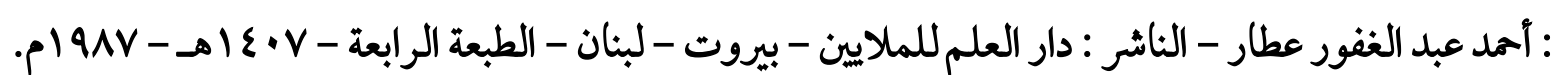

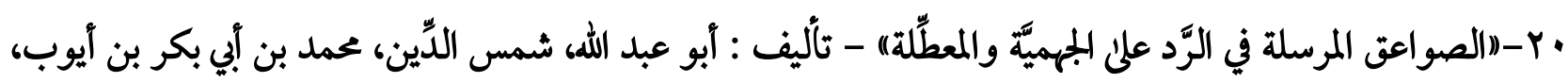

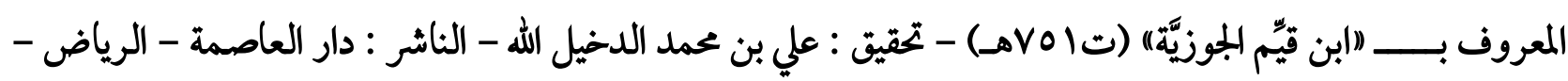

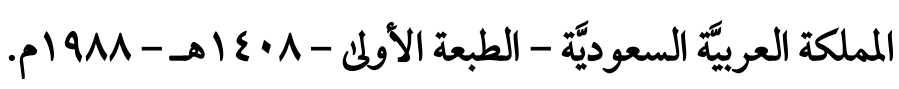

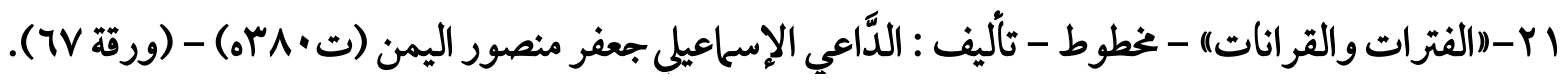

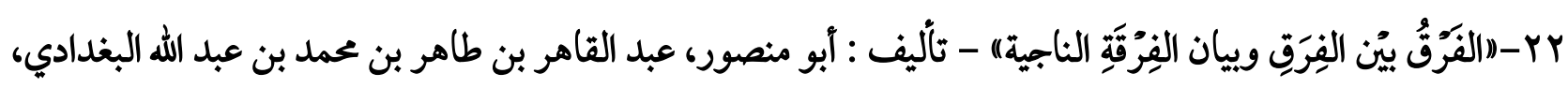

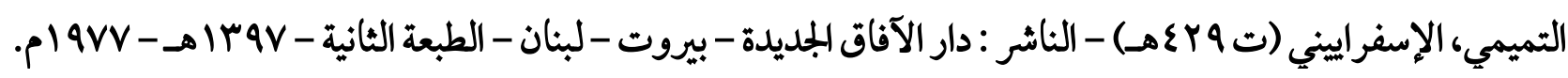
بr - (الفروق اللغويَّة) - تأليف : أبو هلال، الحسن بن عبد اللهبن سهل بن سعيد بن يجيحل بن مهران العسكري (ت 90 بهـ) - تحقيق : محمد إبراهيم سليم - الناشر : دار العلم والثقافة للنشر والتوزيع - القاهرة - مصر.

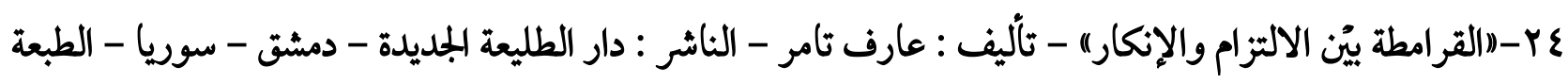

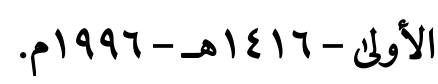

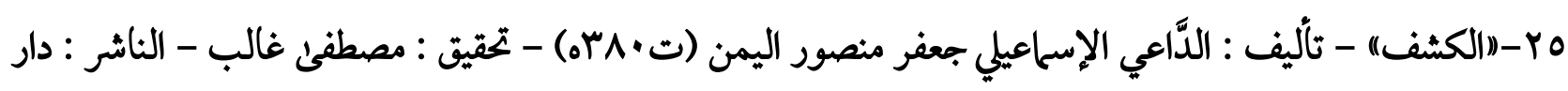

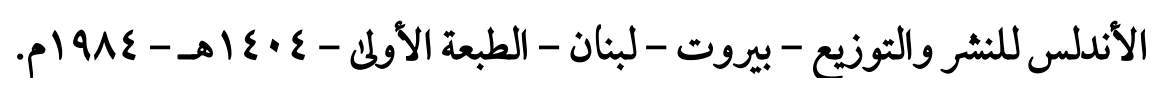
جr-((المجالس المستنصريَّة) - لا يُعرف اسم المؤلّف - تحقيق : محمد كامل حسين - الناشر : دار الفكر العربي - القاهرة -

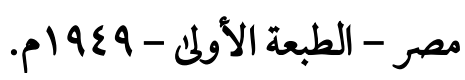

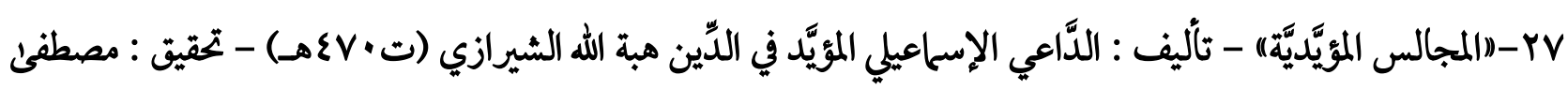
غالب - الناشر : دار الأندلس للطباعة والنشر والتوزيع - بيروت - لبنان. 


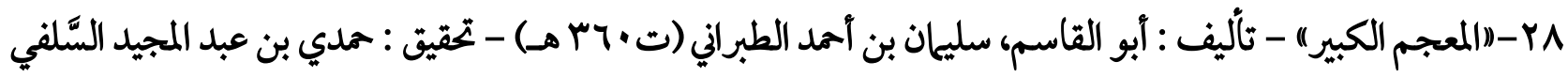

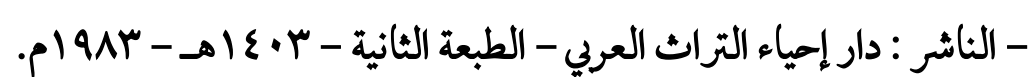

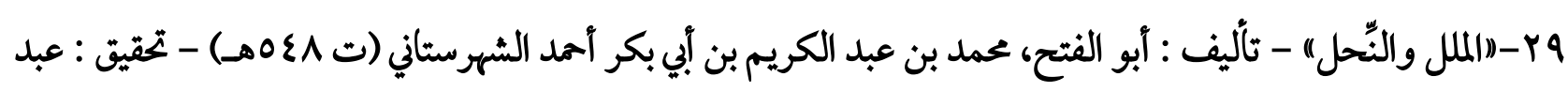

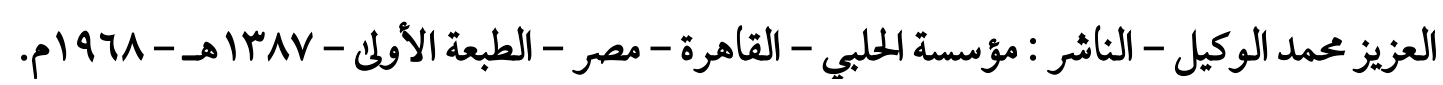

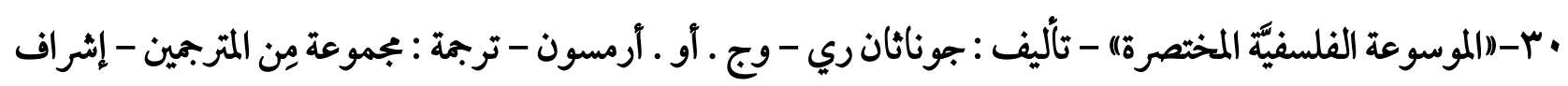

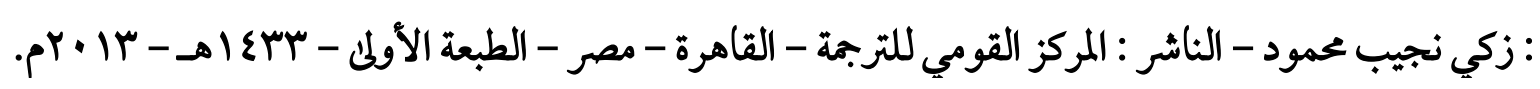

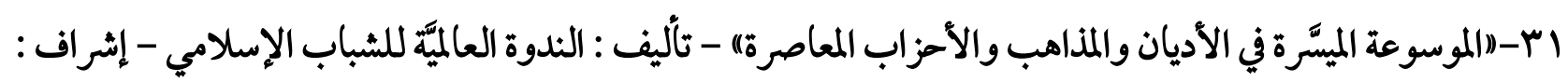

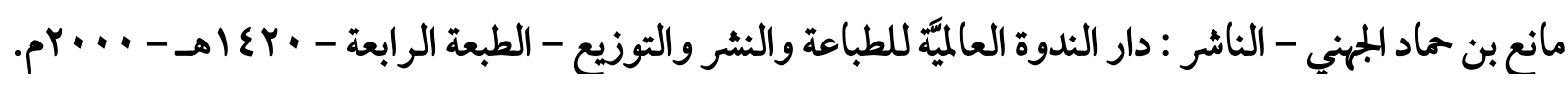

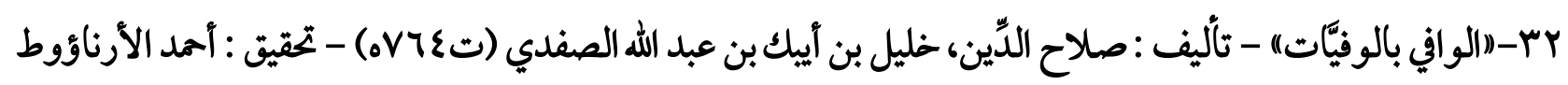

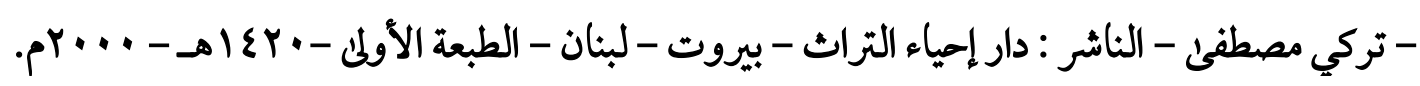

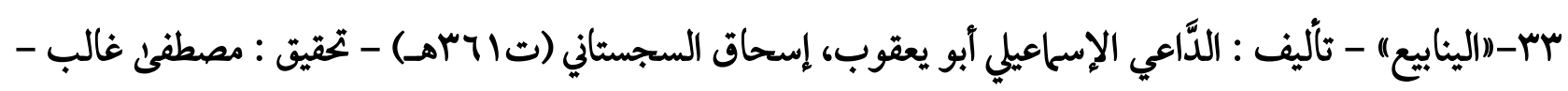

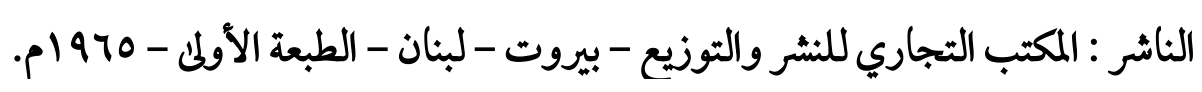

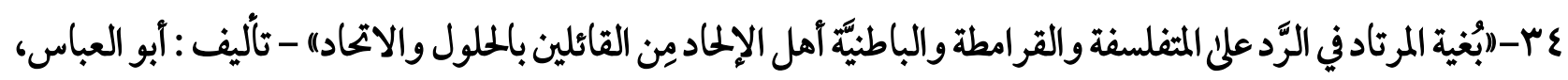

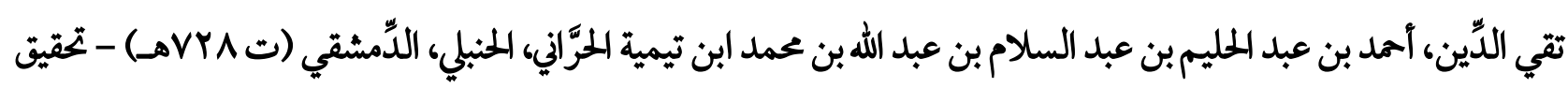

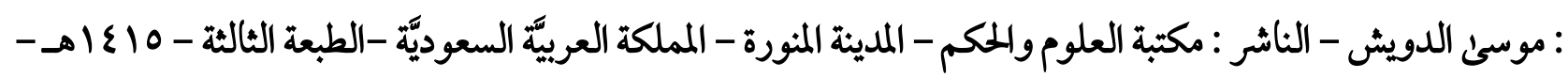
م) 1990 هب-("بيان مذهب الباطنيَّة وبطلانه) - تأليف : محمد بن الحسن الديلمي (ت (VIهـ) - الناشر : مكتبة المعارف - الرياض

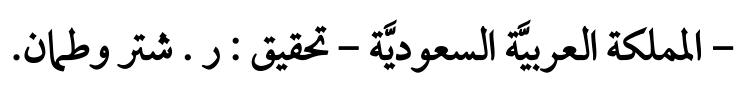

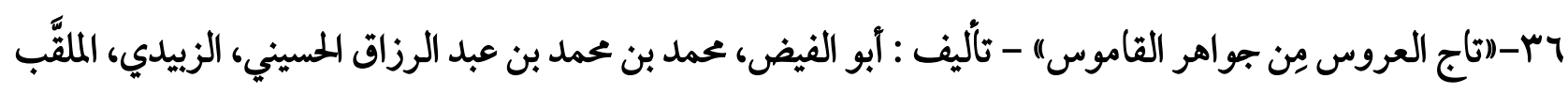

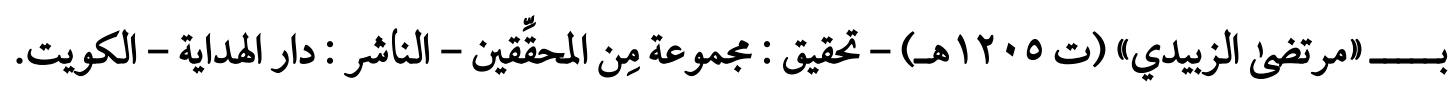

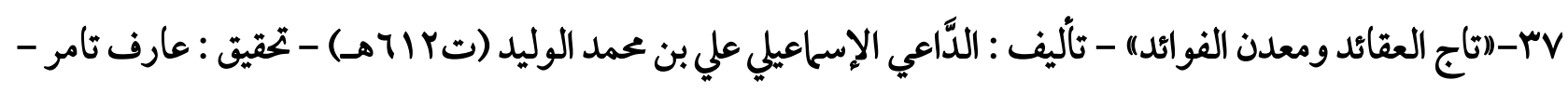

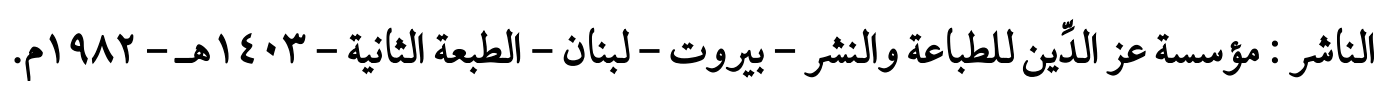

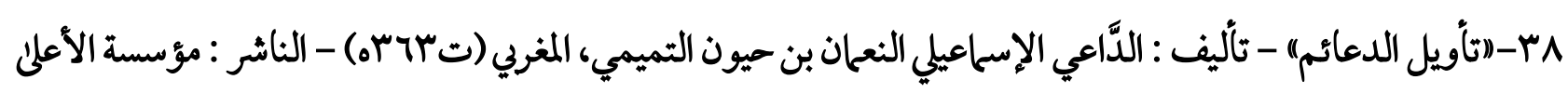

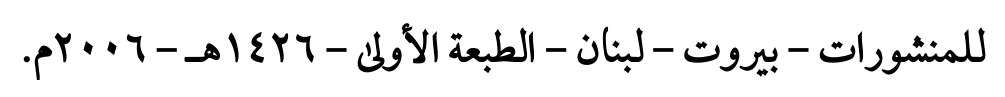
هب- ("تكملة معجم المؤلّفين) - تأليف : محمد خير بن رمضان بن إسماعيل يوسف - الناشر : دار ابن حزم للطباعة والنشر

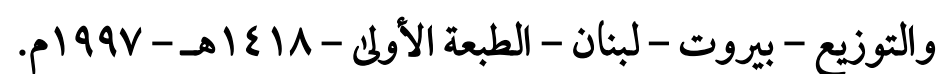

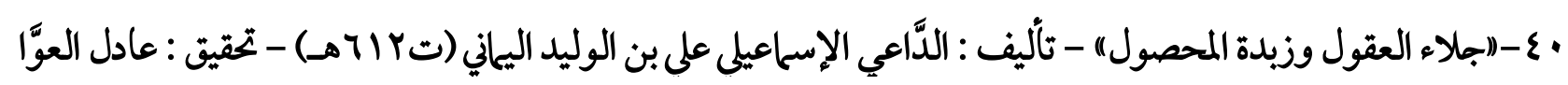


- الناشر : مطبعة البلامعة السوريَّة - دمشق - سوريا.

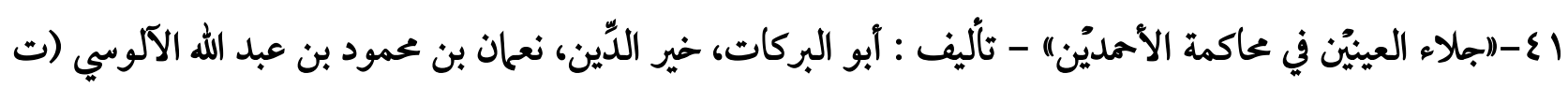

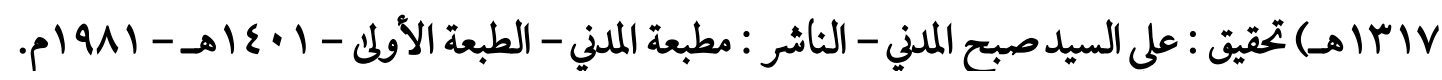

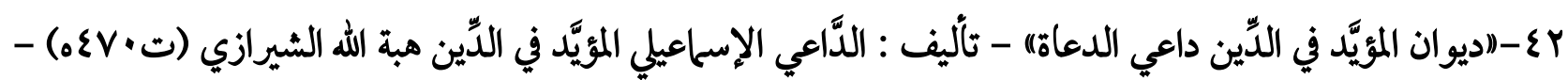

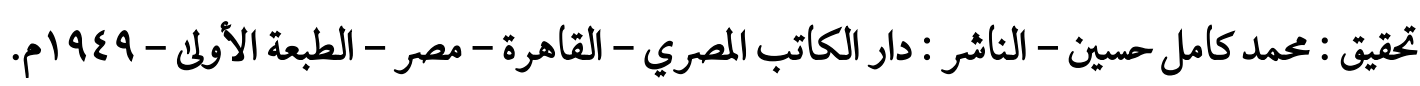

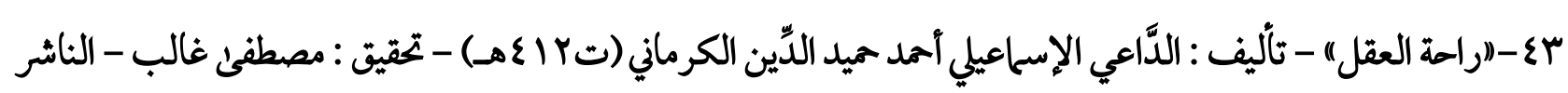

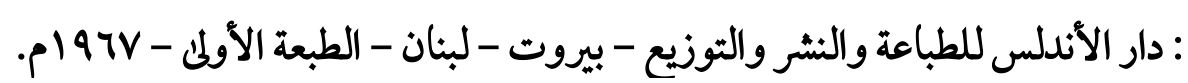

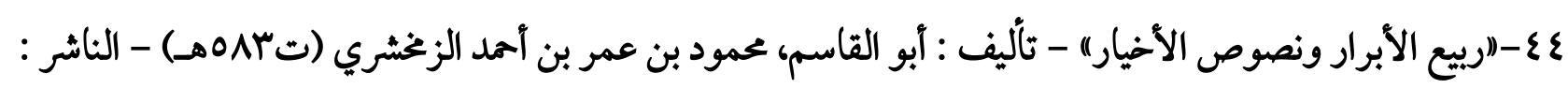

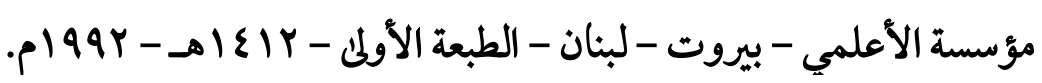

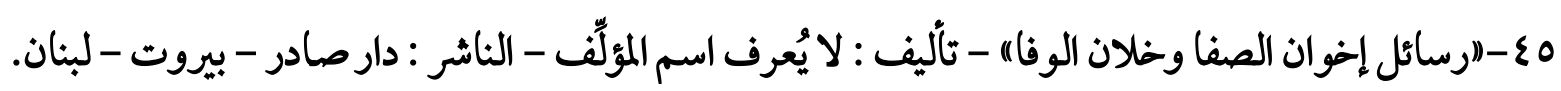

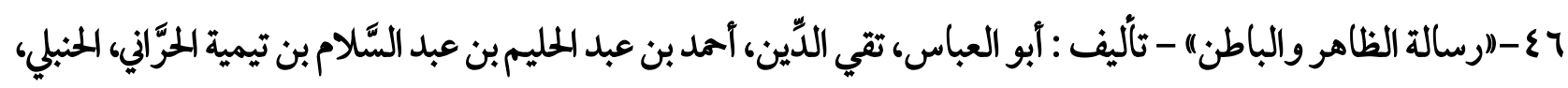

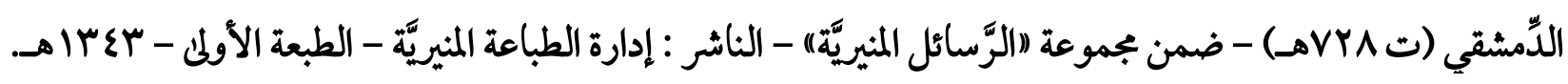

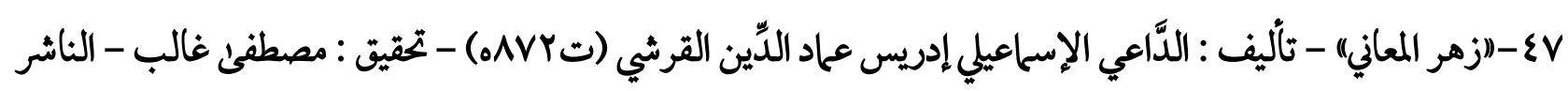

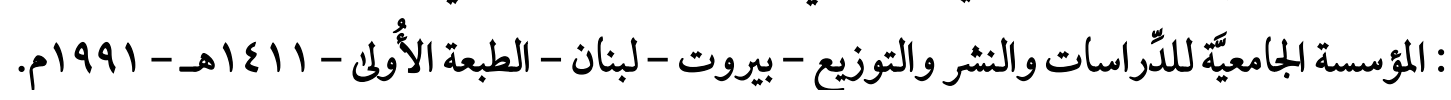

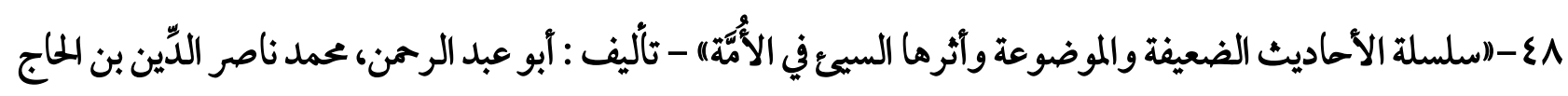

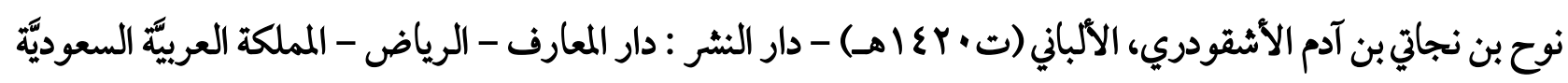

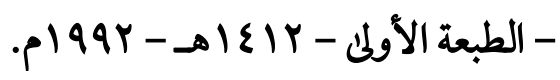

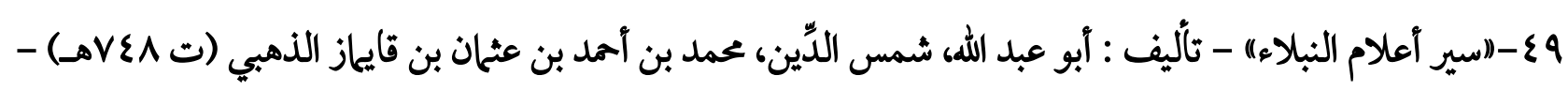

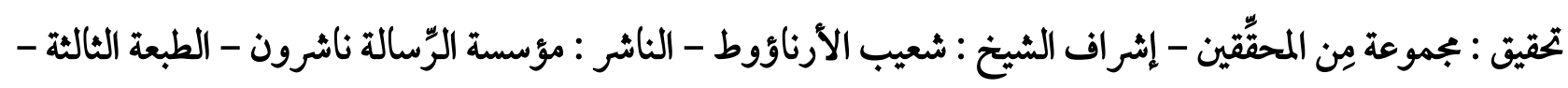

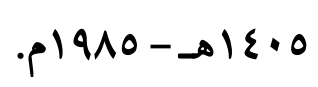

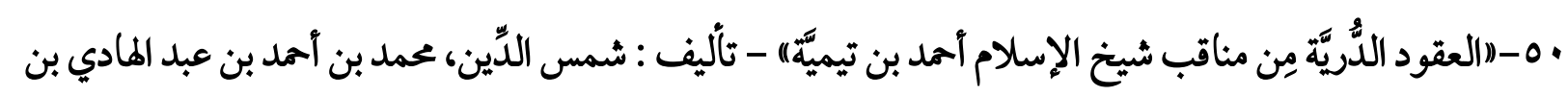

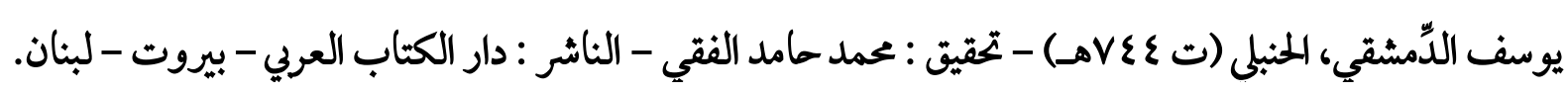

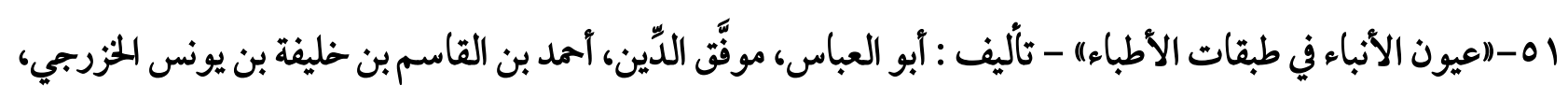

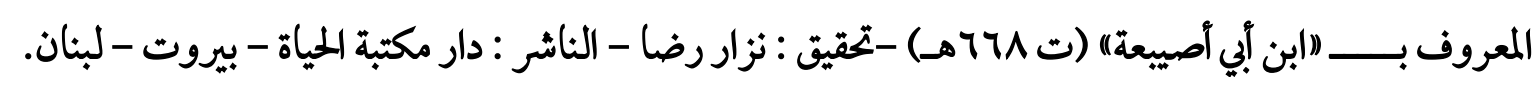

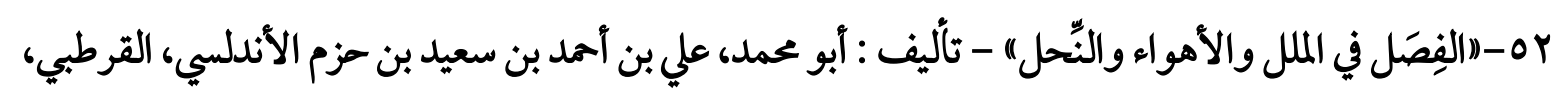
الظاهري (ت الت عهـ) - الناشر : مكتبة اللانجي - القاهرة - مصر.

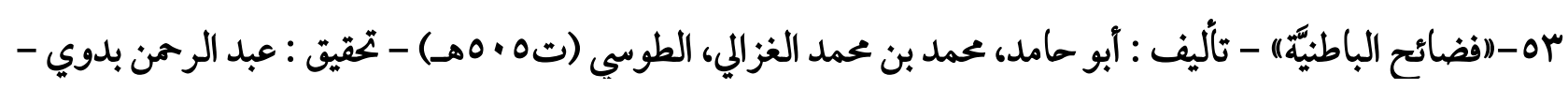


الناشر : مؤسسة دار الكتب الثقافيَّة - حولِّي - الكويت. عه-((في أدب مِصر الفاطميَّة) - تأليف : محمد كامل حسين (ت +497 (19) - الناشر : دار الفكر العربي - القاهرة - مصر -

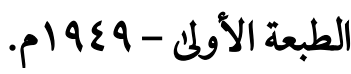
هـ-("قصة الحضارة) - تأليف : ويليام جيمس ديورانت - ترجمة : بجموعة مِن المترجمين - إثراف : زكي نجيب محمود -

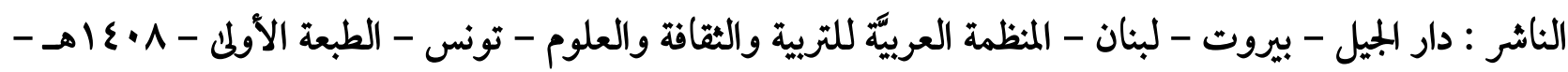
م 7ه-(اقلادة النحر في وفيّات أعيان الدهر) - تألّف : أبو محمد، الطيب بن عبد الله بن أحمد بن علي باغخرمة، المجراني، اللخضرمي، الشافعي (ت V\& 9 هـ) - تحقيق : بو جمعة مكري - خالد زواري - الناشر : دار المنهاج - جدة - المملكة العربيَّة

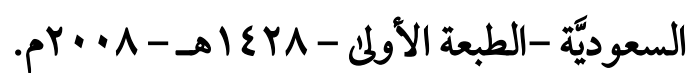

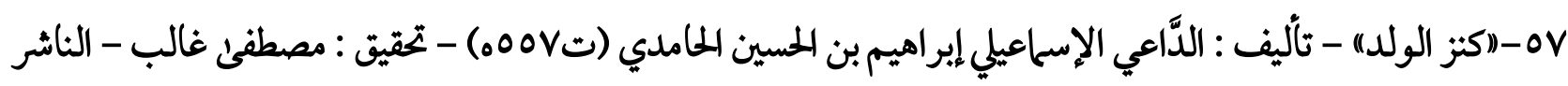
: دار الأندلس للطباعة والنشر والتوزيع - بيروت - لبنان - الطبعة الأولى - 1997 ام. 1ه- (السان العرب) - تأليف : أبو الفضل، جمال الدّين، محمد بن مكرم بن علي بن منظور الأنصاري، الرويفعي، الإفريقي

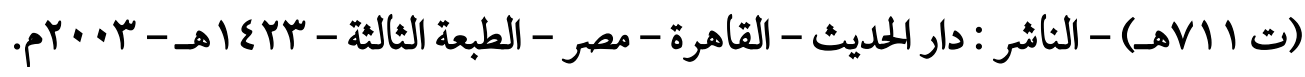

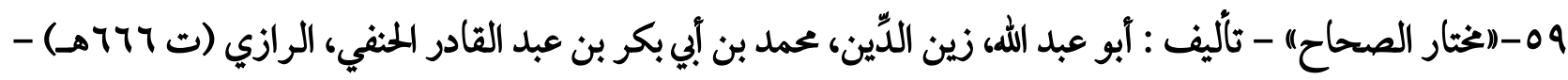

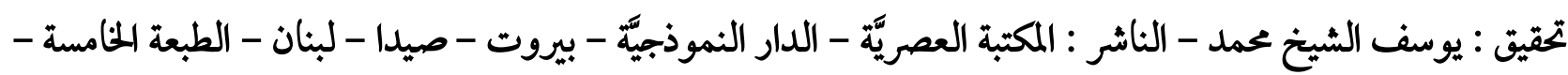
. $1999-ه 1 \varepsilon r$.

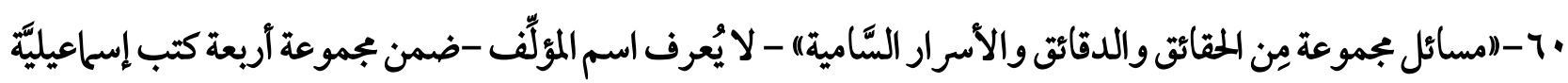

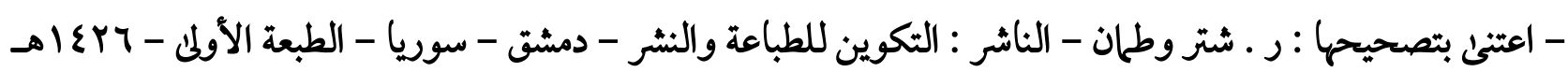
pror

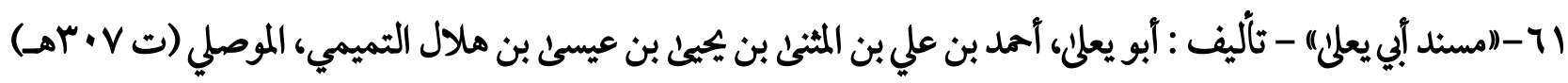

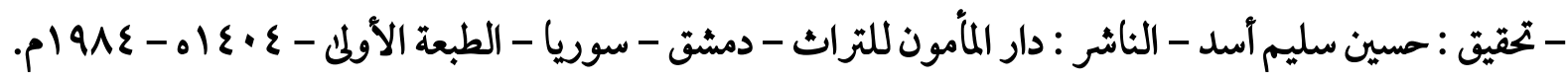

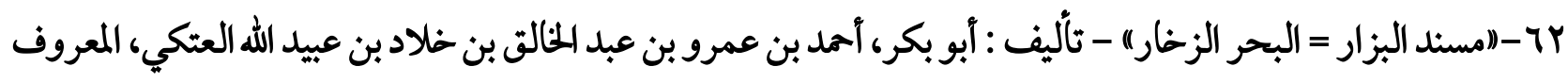

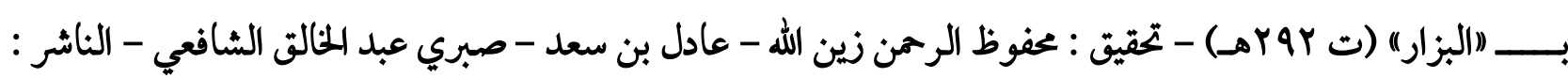

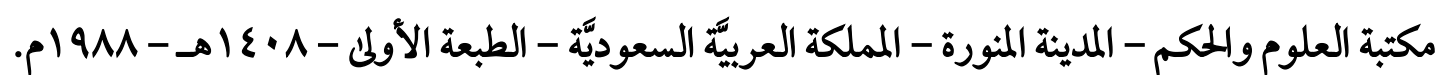

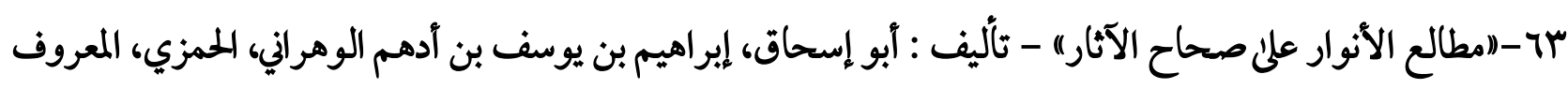

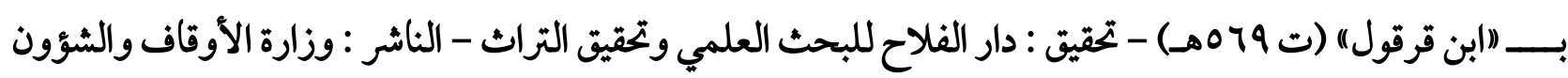

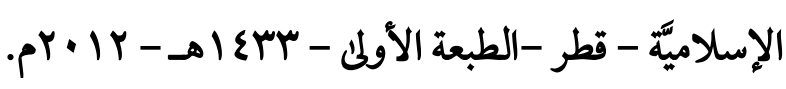




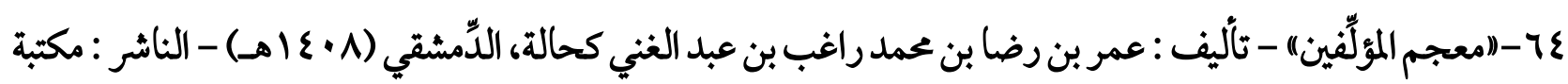
المثنى - دار إحياء التراث العربي - بيروت - لبنان. 10-((مفاتيح المعرفة) - تأليف : مصطفى غالب (1911م) - الناشر : مؤسسة عز الدّرين للطباعة والنشر - بيروت - لبنان

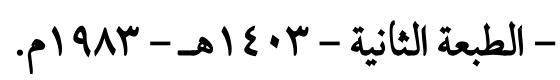

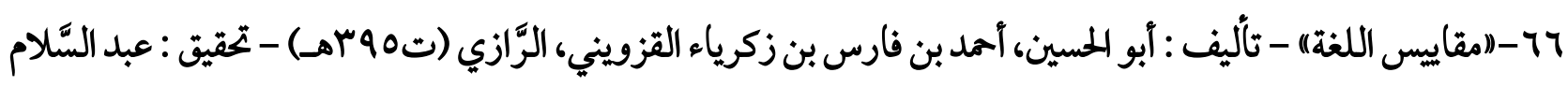

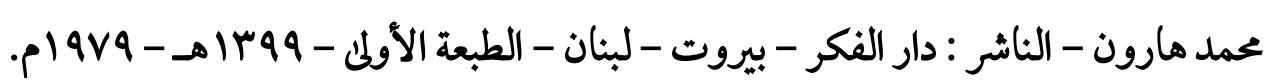

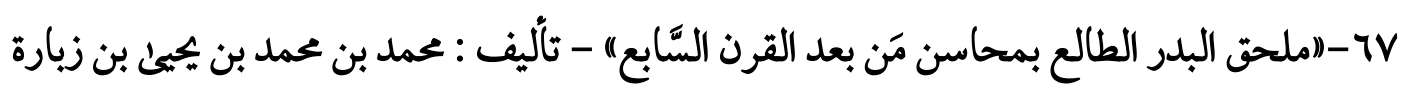

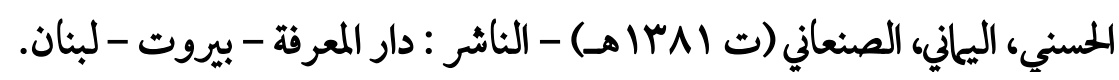

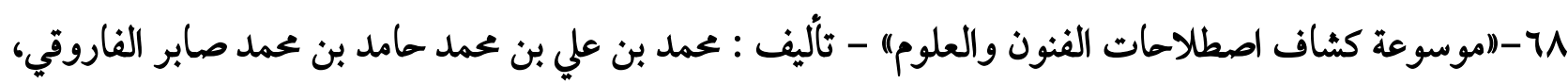
المنفي، التهانوي (ت 101 (1) -هـ) - تحقيق : علي دحروج - الناشر : مكتبة لبنان ناشرون - بيروت - لبنان - الطبعة الأولى . 1997 97-((وفيَّات الأعيان وأنباء أبناء الزمان) - تأليف : أبو العباس، شمس الدِّين، أحمد بن محمد بن إبراهيم بن أبي بكر ابن خلكان البرمكي، الإربلى (ت اله هـ) - تحقيق : إحسان عباس - الناشر : دار صادر - بيروت - لبنان. 


$$
\text { بي }
$$

